NBER WORKING PAPER SERIES

\title{
UNEMPLOYMENT EXPECTATIONS, JUMPING (S,s) TRIGGERS, AND HOUSEHOLD BALANCE SHEETS
}

\author{
Christopher D. Carroll \\ Wendy E. Dunn
}

Working Paper 6081

\section{NATIONAL BUREAU OF ECONOMIC RESEARCH 1050 Massachusetts Avenue \\ Cambridge, MA 02138 \\ July 1997}

We are grateful to Carl Christ, Darrel Cohen, Russell Cooper, Angus Deaton, Karen Dynan, Janice Eberly, Bruce Fallick, James Fergus, Jonas Fisher, Michael Fratantoni, Simon Gilchrist, John Leahy, Jonathan McCarthy, Spencer Krane, Sydney Ludvigson, Greg Mankiw, Randy Mariger, Louis Maccini, David Reifschneider, Martha Starr-McCluer, Daniel Sichel, and seminar participants at Johns Hopkins University, the Board of Governors of the Federal Reserve System, and the 1997 NBER Macroeconomics Annual conference for valuable comments and all sorts of help. The set of RATS programs that generate all of our empirical results, the set of Mathematica programs that generate all of our theoretical results, and a companion paper describing details of our empirical and theoretical methodology are all available at Carroll's home page, http://www.econ.jhu.edu/ccarroll. This work has been supported by a grant from the National Science Foundation to the National Bureau of Economic Research. This paper is part of NBER's research programs in Economic Fluctuations and Growth and Monetary Economics. Any opinions expressed are those of the authors and not those of the National Bureau of Economic Research.

(C) 1997 by Christopher D. Carroll and Wendy E. Dunn. All rights reserved. Short sections of text, not to exceed two paragraphs, may be quoted without explicit permission provided that full credit, including $(\mathrm{C}$ notice, is given to the source. 
Unemployment Expectations, Jumping (S,s) Triggers, and Household Balance Sheets

Christopher D. Carroll and Wendy E. Dunn

NBER Working Paper No. 6081

July 1997

JEL Nos. D1, D8, D9, E2, E3

Economic Fluctuations and Growth

and Monetary Economics

\section{ABSTRACT}

This paper examines the relationship between household balance sheets, consumer purchases, and expectations. We find few robust empirical relationships between balance sheet measures and spending, but we do find that unemployment expectations are robustly correlated with spending. We then construct a formal model of durables and nondurables consumption with an explicit role for unemployment and for household debt. We find that the model is capable of explaining several empirical regularities which are, at best, unexplained by standard models. Finally, we show that a loosening of liquidity constraints can produce a runup in debt similar to that experienced recently in the US, and that after such a liberalization consumer purchases show heightened sensitivity to labor income uncertainty, providing a potential rigorous interpretation of the widespread view that the buildup of debt in the 1980 s may have played an important role in the weakness of consumption during and after the 1990 recession.

Christopher D. Carroll

Department of Economics

Johns Hopkins University

Baltimore, MD 21218-2685

and NBER

ccarroll@jhu.edu
Wendy E. Dunn

Department of Economics

Johns Hopkins University

Baltimore, MD 21218-2685 


\section{Introduction}

The US recession that began in 1990 and the feeble recovery that followed differed from the pattern of previous postwar business cycles in several respects, most notably in the sustained weakness in consumption spending, particularly for durable goods. Blanchard (1993) estimates a simple macroeconomic model and finds that the recession was largely the result of a "consumption shock." Hall (1993) finds an important role for a 'spontaneous decline in consumption,' especially for durable goods. Furthermore, structural macroeconomic models like the FRB-US model substantially overpredicted consumption spending throughout the 1990 recession and especially the early recovery period.

In December 1991, as the economy struggled to make its way out of recession, Federal Reserve Chairman Alan Greenspan included the following statements in Congressional testimony on the state of the economy:

During the 1980s, large stocks of physical assets were amassed in a large number of sectors, largely financed by huge increases in indebtedness... In the household sector, purchases of motor vehicles and other consumer durables ran for several years at remarkably high levels and were often paid for with installment or other debt that carried extended maturities. In some parts of the United States, the household spending boom reached to the purchase of homes... The aftermath of all this activity is a considerable degree of financial stress in the household sector. (Greenspan (1992)).

In this testimony and elsewhere, Greenspan consistently blamed the 1990-1991 recession and the subsequent painfully slow recovery on the "deteriorated balance sheets" of both firms and households resulting from the buildup of debt in the 1980s. Figure 1 shows that the runup in household debt in the 1980s was indeed impressive. Most of this growth was in mortgage debt, spurred by the financial deregulation of the early 1980 s which led to low down payment requirements on home purchases.

The problematic part of what we will call the "Greenspan Hypothesis" is that it provides no explanation for why balance sheet positions that consumers voluntarily chose in the spring and summer of 1990 were suddenly a major contractionary force in the fall of 1990 and in 1991 . One plausible possibility is that an aggregate 'target' consumer balance sheet position depends, among other things, on the degree of consumers' uncertainty about the future, and in particular on their perceptions about 


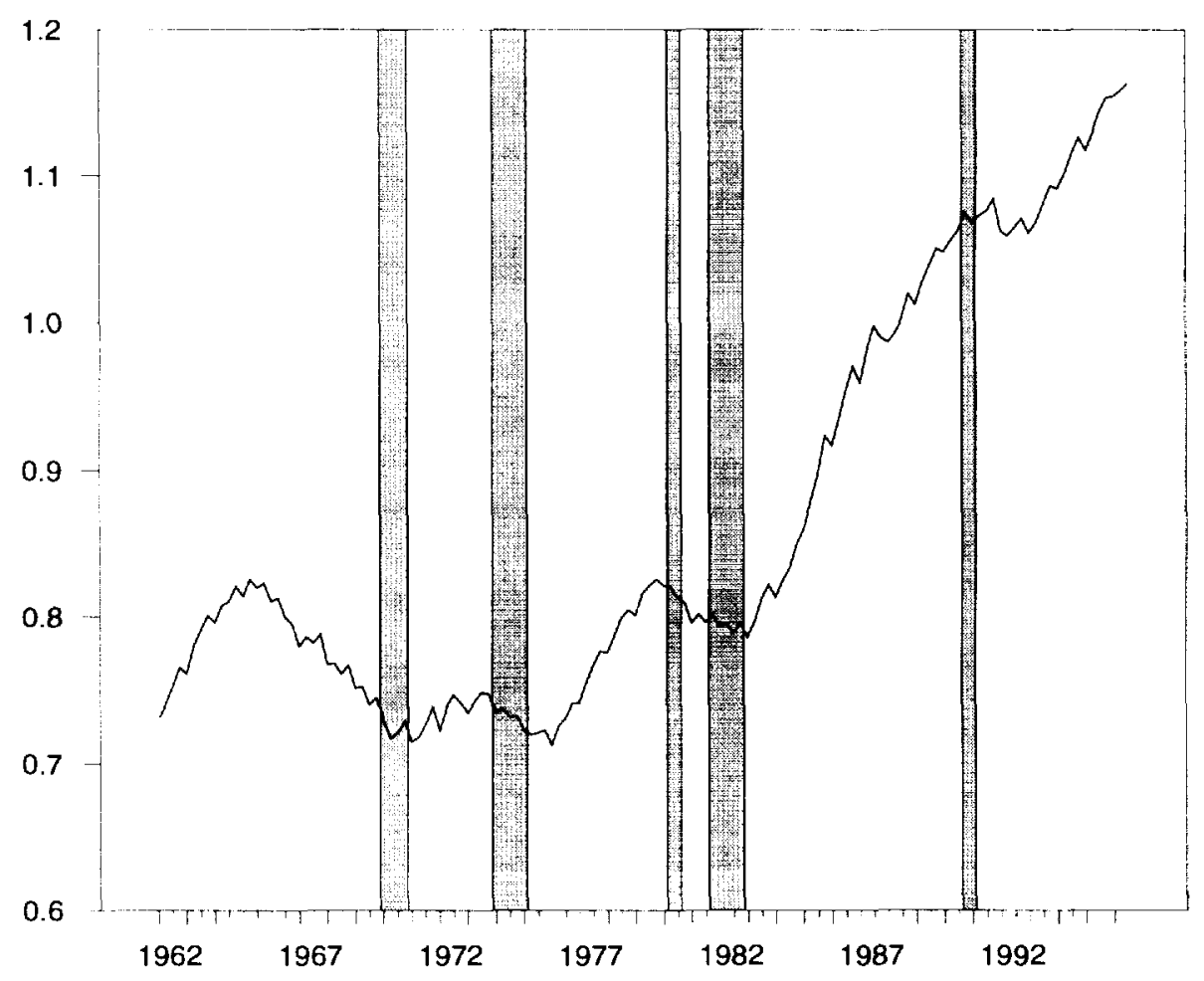

Figure 1: Debt To Income Ratio

the risk of future unemployment spells. Figure 2 plots the best available data on household unemployment expectations, from the University of Michigan's monthly surveys of consumers. ${ }^{1}$ Unemployment expectations deteriorated sharply in the fall of 1990 , right at the time of the 'spontaneous' consumption drop. ${ }^{2}$ The natural interpretation is that it was the deterioration in unemployment expectations that converted a balance sheet position which consumers had voluntarily chosen in happier times into one that required serious 'repair.' Indeed, it might appear tempting to attribute the consumption drop in 1990 entirely to the deterioration in sentiment and to dismiss the condition of household balance sheets as a sideshow. ${ }^{3}$ One difficulty of this interpretation, however, is that unemployment expectations always deteriorate near the beginning of a recession (see Figure 2 again), and the 1990

\footnotetext{
${ }^{1}$ The index is equal to the fraction of consumers surveyed who thought unemployment would rise over the next twelve months minus the fraction who thought unemployment would fall.

${ }^{2}$ We choose this unemployment expectations index to measure consumer sentiment for several reasons. First, it has a. much clearer definition than the more commonly used overall measures of sentiment, which combine in arbitrary ways the answers to questions about the past, present, and fut ure conditions in a variety of largely unrelated markets. Second. one of the principal theoretical results in the precautionary saving literature is that large shocks like unemployment spells should be disproportionately important in determining behavior as compared with small shocks such as wage fluctuations for employed consumers. Finally, the unemployment expectations index is considerably more robustly correlated with most measures of spending than are overall sentiment measures.

${ }^{3}$ Both Blanchard (1993) and Hall (1993) suggest that the decline in sentiment was important, but neither emphasizes balance sheet issues.
} 


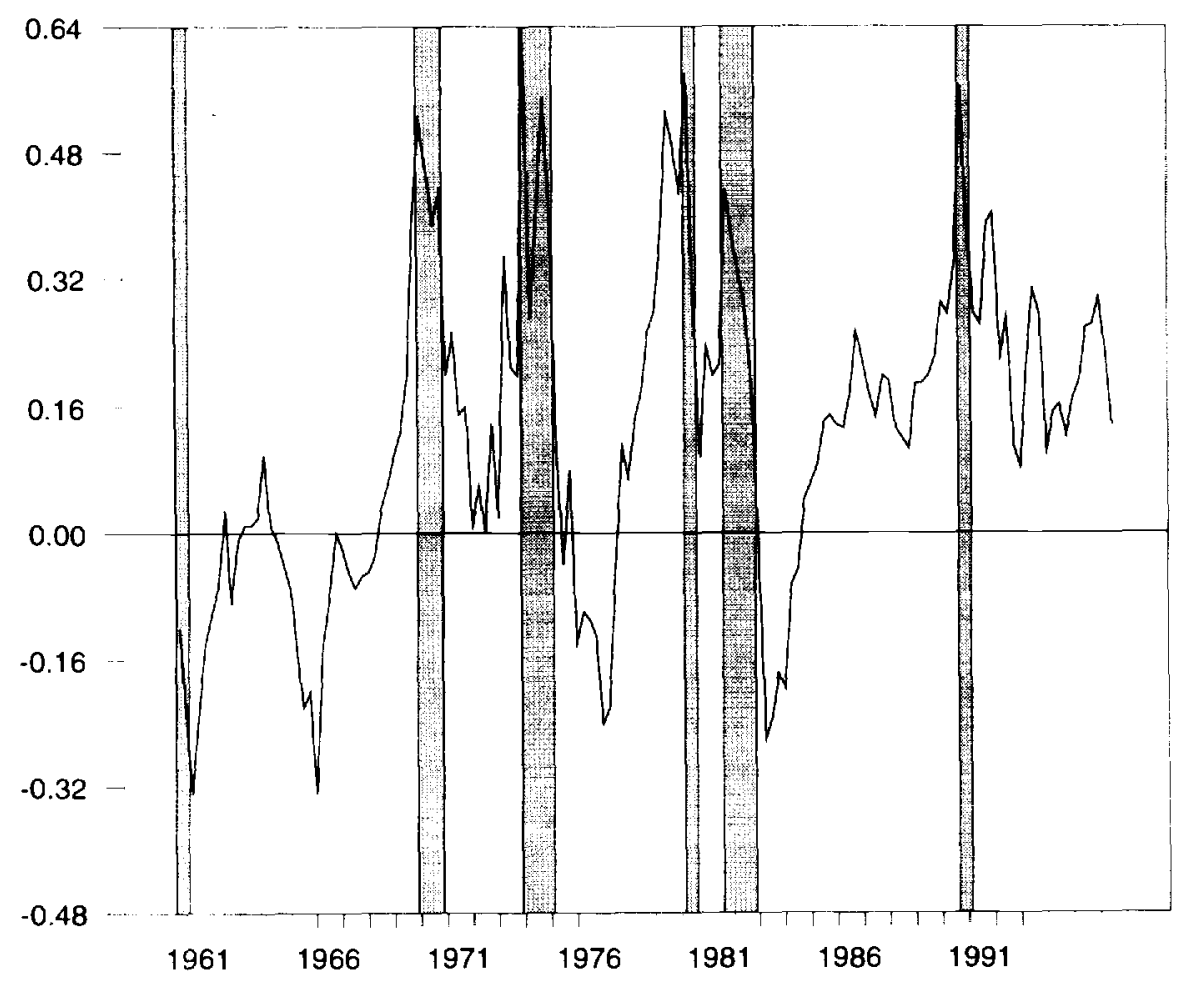

Figure 2: Unemployment Expectations

experience was not sufficiently different from previous recessions to explain why consumption growth was weaker than it usually is during recessions. The behavior of the unemployment expectations index was more unusual after the trough of the recession; usually the index plummets just after the trough, but unemployment expectations remained quite high for a long time after the 1991 trough. ${ }^{4}$ Still, even consumption models which incorporate the unemployment expectations index have large negative residuals during and after the 1990 recession, implying that the consumption weakness cannot be explained as simply reflecting consumer pessimisin.

Prompted by this debate, this paper is a broad attempt to make sense of the relationship between household balance sheets, unemployment expectations, and household purchases. We begin (in Section 2) by documenting what we take to be the main stylized facts about the empirical relationships between consumer purchases, household balance sheets, and uncertainty. The only systematic relationship we are able to uncover between balance sheet measures and spending is a robust positive correlation between lagged debt growth and the current level of spending on durables, a relationship

\footnotetext{
${ }^{4}$ It is interesting to note that the index was 'right', in the sense that the unemployment rate did remain unusually high for an unusually long period after the trough.
} 
which is most easily interpreted as reflecting simultaneity rather than a causal link. However, we do identify another empirical regularity: our preferred measure of uncertainty, the lagged value of the Unemployment Expectations index plotted in Figure 2, is robustly correlated with every measure of consumer spending, even after controlling for 'permanent income' as best we can (and in particular after controlling for whatever information unemployment expectations contain about future income).

With these results in mind, we then (in Section 3) construct a theoretical model of the durable goods purchase problem for consumers who face the possibility of unemployment spells. Because analytical solutions are not available when there is labor income uncertainty, we solve the model numerically. We find that the model implies that a rise in uncertainty causes consumers to delay durables purchases (formally, the lower trigger of the $(\mathrm{S}, \mathrm{s})$ rule jumps down; hence our title). We then compare simulation results from the model with our empirical evidence for the US economy, and find that the model explains some but not all of the empirical findings. In particular, the model implies a much stronger role for changes in unemployment expectations, and a weaker role for the lagged level of unemployment expectations, than we find in the data. Finally, in Section 6, we show that the model implies that a financial liberalization which loosens liquidity constraints will cause a runup in aggregate debt like the runup shown in figure 1, and that in the liberalized economy the reaction of durables purchases to uncertainty is intensified. Thus our model potentially rationalizes the idea that the runup of consumer debt in the 1980 s was partly responsible for the puzzling weakness of consumption spending during and after the 1990 recession. Furthermore, the model implies that the continuing growth of the debt ratio may be making consumption increasingly vulnerable to swings in consumer sentiment.

\section{Empirical Results}

\subsection{Balance Sheets and Nondurables Consumption Growth}

Although housing and other durable goods account for most of the volatility of consumption spending over the business cycle, we begin our empirical work by examining spending on nondurable goods. Partly this is because virtually no existing work has examined the effect of either balance sheets or time-varying unemployment expectations on nondurables spending, and these are important questions in their own right. Partly, we examine nondurables because one of the innovations of our theoretical 
model is our joint treatment of durables and nondurable goods. ${ }^{5}$ Thus, in principle, even in the absence of time-varying unemployment risk our model might generate different predictions for nondurables spending than standard models.

The benchmark model with which we intend to compare both empirical results and the theoretical predictions of our model is the representative agent, certainty equivalent version of the Permanent Income model (henceforth, CEQ PIH model), as used, for example, by Campbell (1987), Campbell and Deaton (1989), and many others. In this model, consumption is equal to "permanent income" defined as the annuity value of total wealth, human and nonhuman:

$$
\begin{aligned}
C_{t} & =\frac{r}{1+r}\left[W_{t}^{h}+W_{t}^{n}\right] \\
W_{t}^{h} & =\sum_{s=t}^{\infty}\left(\frac{1}{1+r}\right)^{s-t} Y_{s}
\end{aligned}
$$

where $Y_{s}$ is total noncapital income (labor income plus net transfers) in period $s$. We define a variable which we will call "annuity labor income" $A_{t}$ as the annuity value of human wealth: ${ }^{6}$

$$
A_{t}=\frac{r}{1+r} W_{t}^{h}
$$

As Hall (1978) famously pointed out, one of the implications of this model is that lagged information should have no predictive power for current consumption growth. Campbell and Mankiw (1989) showed that all of the empirical failures of the CEQ PIH model could be explained by a model in which a fraction $\lambda$ of aggregate labor income goes to rule-of-thumb consumers who simply spend all available income in each quarter while $(1-\lambda)$ of income accrues to consumers who behave according to the CEQ PIH model. These assumptions, plus a few approximations, lead to an estimating equation of the form:

$$
\Delta \log C_{t}=\gamma_{0}+\gamma_{1} E_{t-1} \Delta \log Y_{t}+\epsilon_{t}
$$

where the expectation is taken with respect to a set of instruments dated $t-1 .^{7}$ Because, strictly

\footnotetext{
${ }^{5}$ Most previous modelling efforts, with the exception of Bernanke (1985), have assumed utility flows either solely from nondurables or solely from durables, or at the very least that utility from durables and nondurables is separable.

${ }^{6}$ We adopt this terminology partly to avoid confusion between the variable in this model and the "permanent labor income" variable in our theoretical model.

${ }^{7}$ Because time aggregation can introduce an MA(1) error term, the usual procedure is to use instruments dated $t-2$. However, as Carroll, Fuhrer, and Wilcox (1994) argue, this unnecessarily discards potentially valuable information in variables dated $t-1$. We follow those authors in pursuing a nonlinear estimation methodology that allows us to use instruments dated $t-1$ and to impose the orthogonality restriction directly. Our instruments for income growth are the same as those used by Carroll, Fuhrer, and Wilcox (1994): three lags each of income growth, consumption growth,
} 
speaking, the model applies only to the consumption of nondurables, our measure of consumption is spending on nondurable goods from the NIPA accounts. ${ }^{8}$

Results are contained in Table 1. Our first regression reproduces the basic result of Campbell and Mankiw (1989): the coefficient on predictable income growth is enormously statistically significant (with a t-statistic of over 4 ), and suggests that rule-of-thumb consumers earn roughly half of aggregate labor income. Our second regression performs a simple Hall-style test of whether lagged unemployment expectations are useful in predicting current consumption growth. Again the answer is overwhelmingly yes; the t-statistic is 3.7 . Our next regression reconfirms the main result of Carroll, Fuhrer, and Wilcox (1994): the lagged level of consumer sentiment (as measured by unemployment expectations) contains substantial predictive power for consumption growth even after controlling for the information sentiment contains about income growth. ${ }^{910}$

Turning now to the role of balance sheet variables, our goal is to test whether such variables violate the benchmark sentiment-augmented Campbell-Mankiw model presented in row 3 of Table 1. In our background empirical work we examined a broad set of measures of household balance sheet conditions, but in the paper we present results for only three measures; the ratio of liabilities to annuity labor inconc, the ratio of liabilities to assets, and the growth rate of liabilities. ${ }^{11}$ None of the other balance sheet variables we examined performed better (in the sense of being more highly correlated with the dependent variables we are interested in) than these three variables. ${ }^{12}$

the change in the three-month T-bill rate, the change in the unemployment rate, and the growth of the S\&P 500 index, one lag of the log difference between consumption and income and of the measure of sentiment being tested (in our case, unemployment expectations; in the Carroll, Fuhrer, Wilcox paper, overall consumer sentiment). The adjusted $R^{2}$ on the first-stage regression for income growth is 0.41 .

${ }^{8}$ The model is often estimated on the sum of nondurables and services consumption. However, in the 'final' version of NIPA data, substantial parts of services consumption are constructed using quarterly interpolation through annual estimates, where the later endpoint for the interpolation is strictly in the future of some of the quarterly estimates of services spending it is used to construct. This potentially introduces spurious time-series properties into the services component of spending which are most easily avoided by excluding services from the measure of consumption. For more discussion of these points, see Wilcox (1992).

${ }^{9}$ Carroll, Fuhrer, and Wilcox used the overall index of consumer sentiment rather than the unemployment expectations index we use here; also. they tested for the joint significance of four lags of sentiment, rather than just a single lag as we do.

${ }^{10}$ When lagged unemployment expectations are added to the Campbell-Mankiw equation, the coefficient estimate on forecastable income growth is about half of its previous value and just misses being statistically significant (the $\mathrm{p}$-value is .103). The reason the statistical significance of the forecastable part of income growth drops so dramatically when lagged unemployment expectations are included in the regression is that lagged unemployment expectations are highly correlated with the forecastable component of income growth. Whether income growth is significant, lagged unemployment expectations are signficant, or neither is significant is somewhat sensitive to the choice of instruments; in particular, if the instrument set does not contain variables that provide substantial information about income growth that is independent of the information about income growth contained in unemployment expectations, typically neither income growth nor unemployment expectations is individually significant.

${ }^{11}$ See below for a discussion of how we constructed our estimate of annuity labor income.

${ }^{12}$ We also examined the ratio of debt to net worth. the ratio of debt to liquid assets, the ratio of debt to current income, and the ratio of the debt service burden to annuity income, among others. 
Nondurable Consumption Growth

Quarterly Data, 1963:3-1994:3

\begin{tabular}{|c|c|c|c|c|c|c|c|}
\hline Row & $\begin{array}{c}\text { Balance } \\
\text { Sheet } \\
\text { Measure }\end{array}$ & $E_{t-1} \Delta \log Y_{t}$ & $\mathrm{UE}_{t-1}$ & $\begin{array}{c}\text { Balance } \\
\text { Sheet }\end{array}$ & $\theta$ & SSR & D-W \\
\hline 1 & & $\begin{array}{c}0.509 \\
(4.13)^{* * *}\end{array}$ & & & $\begin{array}{r}0.086 \\
(0.93)\end{array}$ & 0.49 & 1.98 \\
\hline 2 & & & $\begin{array}{c}-1.310 \\
-(3.69)^{* * *}\end{array}$ & & $\begin{array}{r}0.136 \\
(1.47)\end{array}$ & 0.58 & 1.97 \\
\hline 3 & & $\begin{array}{r}0.269 \\
(1.64)\end{array}$ & $\begin{array}{c}-0.906 \\
-(2.18)^{* *}\end{array}$ & & $\begin{array}{r}0.092 \\
(0.99)\end{array}$ & 0.50 & $1 . \overline{98}$ \\
\hline 4 & $\Delta \log D_{t-1}$ & $\begin{array}{r}0.246 \\
(1.50)\end{array}$ & $\begin{array}{r}-0.690 \\
-(1.55)\end{array}$ & $\begin{array}{c}0.095 \\
(1.33)\end{array}$ & $\begin{array}{r}0.088 \\
(0.94)\end{array}$ & 0.49 & 2.00 \\
\hline 5 & $r D_{t-1} / Y_{t-1}$ & $\begin{array}{r}0.257 \\
(1.57)\end{array}$ & $\begin{array}{c}-0.820 \\
-(1.90)^{*}\end{array}$ & $\begin{array}{r}-0.073 \\
-(0.93)\end{array}$ & $\begin{array}{c}0.0937 \\
(1.00)\end{array}$ & 0.49 & 1.98 \\
\hline 6 & $D_{t-1} / A_{t-1}$ & $\begin{array}{r}0.247 \\
(1.45)\end{array}$ & $\begin{array}{c}-0.906 \\
-(2.15)^{* *}\end{array}$ & $\begin{array}{r}-0.002 \\
-(0.33)\end{array}$ & $\begin{array}{c}0.096 \\
(1.02)\end{array}$ & 0.50 & 1.97 \\
\hline
\end{tabular}

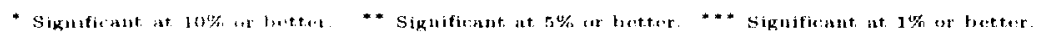

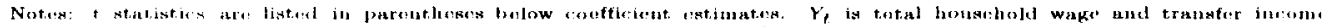

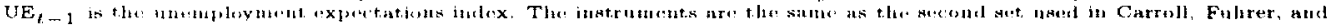

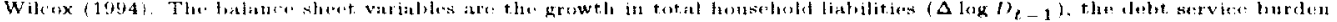

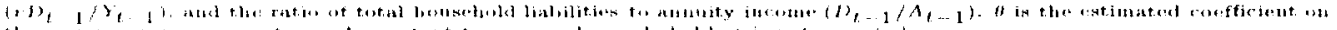

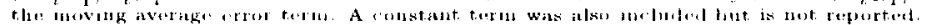

Table 1: The Sentiment-Augmented Campbell-Mankiw Model

Our empirical test is simply whether lagged balance sheet variables are statistically significant when we add them to the sentiment-augmented Campbell-Mankiw model. ${ }^{13}$ As rows 4 through 6 of the table show, none of the balance sheet variables is statistically significant in any of the regressions. ${ }^{14}$ Thus, there is little evidence that household balance sheet conditions have any influence on nondurables consumption growth that operates through any channel outside of the sentiment-augmented CampbellMankiw model..$^{15}$

We now turn to the question of the relative importance for nondurables consumption of innovations to annuity income and to unemployment expectations. This question is of central importance to the

\footnotetext{
${ }_{13}$ Of course. we also add then to the set of instruments used for predicting income growth.

${ }^{14}$ The debt to annuity income variable appears to be nonstationary, while consumption growth is approximately stationary; econometric theory implies that for a large enough time sample, the coefficient in a regression of a stationary variable on a nonstationary one must yield a zero coefficient, so the insignificance of this variable is hardly surprising.

${ }^{15}$ These results are somewhat at variance with previous results of Ludvigson (1996), who found that predictable debt growth was significantly related to consumption growth. We were able to reproduce Ludvigson's results, and have determined that there are four reasons for the differences in outcomes. First, our measure of consumption spending is restricted to nondurable goods, while Ludvigson followed most of the previous literature by examining spending on nondurable goods and services. We believe that the data construction methods for the quarterly services expenditures render those data unsuitable for regressions of this kind. Second, because our focus is on the overall structure of household balance sheets, our measure of debt is total household liabilities, while Ludvigson's balance sheet variable was consumer installınent credit. i.e. mainly debt exclusive of mortgages. Third, Ludvigson's test was whether consumption growth was related to predictable debt growth, while our test is a more direct test of the Campbell-Mankiw model: whether lagged debt growth matters. Finally, Ludvigson was using the standard Campbell-Mankiw model as her baseline rather than the sentiment-auginented model we are using (although our result that lagged debt growth is insignificant holds up even when we estimate a standard (non-sentiment-augmented) Campbell-Mankiw model).
} 
enterprise of this paper because the answer should help to inform us whether ignoring fluctuations in uncertainty is a small omission that is well worth the associated modelling dividend of analytical tractability, or a large omission, so that any model which ignores uncertainty is likely to tell a seriously incomplete story about the determinants of consumption over the business cycle.

To examine this issue (and many others we will introduce later in the paper) we need an estimate of the level of annuity income. We construct two estimates, first following a method used to estimate annuity personal disposable income in the FRB-US model at the Federal Reserve Board, then using a method of our own devising. The FRB-US methodology $\left(A_{t}^{\text {FRB-us }}\right)$ is based on an assumption that the ratio of personal income to GDP is stationary and that the GDP gap is stationary. A VAR forecasting system is used to estimate the projected future output gap XGAP and the projected future gap in the ratio of income to GDP. YGAP. The VAR system includes equations for inflation, the fed funds rate, XGAP, and YGAP. Wo also added four lags of income growth and the unemployment expectations variable to each equation. ${ }^{16}$

Our own annuity labor income measure $\left(A_{t}^{\text {our }}\right)$ is created by forecasting the present discounted value of the sum of the next two years of labor income using a set of forecasting variables drawn from the Carroll, Fuhrer, and Wilcox (1994) set of instruments for income growth. We make the assumption that beyond two years income is expected to grow at a constant rate equal to the average growth rate over the entire sample period. Using this growth rate, we calculate the annuity value of income from two years to infinity and add this to the forecasted discounted sum of income over the next two years to get $A_{t}^{\text {(our. }}$. For more details on the two methods of constructing annuity income, see the companion methodology paper Carroll and Dumn (1997).

In principle, if our estimate of the imnovation to annuity income were perfect (or, more realistically, if the variables we use to construct the measure are valid instruments for annuity income growth) then the following equation would characterize nondurable consumption growth in the Campbell-Mankiw model:

$$
\Delta \log C_{t}=(1-\lambda) E_{t-1} \rho^{-1}\left(r_{t}-\delta\right)+\lambda \Delta \log Y_{t}+(1-\lambda) \Delta \log A_{t}
$$

Hence we could obtain an estimate of the fraction of income accruing to CEQ PIH income consumers

\footnotetext{
${ }^{16}$ We are grateful to David Reifschneider at the Federal Reserve for explaining the FRB-US methodology to us. Because we are adapting the FRB-US methodology to a purpose quite different from its intended purpose, and because we are using a different measure of income, any empirical inadequacies of the annuity income measure we construct using the FRB-US methodology should be laid at our doorstep, not the FRB-US model staff's.
} 
Nondurable Consumption Growth

Quarterly Data, 1963:3-1994:3

\begin{tabular}{|l|c|c|c|c|c|c|r|}
\hline Row & $\Delta \log Y_{t}$ & $\Delta \log A_{t}^{\text {(*)I** }}$ & $\Delta \log A_{t}^{\text {FRB-Us }}$ & $\mathrm{UE}_{t-1}$ & $\Delta \mathrm{UE}_{t}$ & $\bar{R}^{2}$ & D-W \\
\hline 1 & 0.326 & 0.186 & & -0.833 & & 0.33 & 1.83 \\
& $(3.15)^{* * *}$ & $(2.82)^{* * *}$ & & $-(2.55)^{* * *}$ & & & \\
\hline 2 & 0.324 & 0.124 & & -1.003 & -0.907 & 0.34 & 1.92 \\
& $(3.15)^{* * *}$ & $(1.59)$ & & $-(2.92)^{* * *}$ & $-(1.52)$ & & \\
\hline 3 & 0.391 & & 0.189 & -0.654 & & 0.29 & 1.92 \\
& $(3.41)^{* * *}$ & & $(1.20)$ & $-(2.00)^{* *}$ & & & \\
\hline 4 & 0.394 & & 0.000 & -0.981 & -1.413 & 0.32 & 2.00 \\
& $(3.50)^{* * *}$ & & $(0.00)$ & $-(2.83)^{* * *}$ & $-(2.47)^{* *}$ & & \\
\hline
\end{tabular}

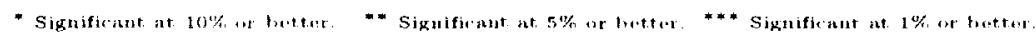

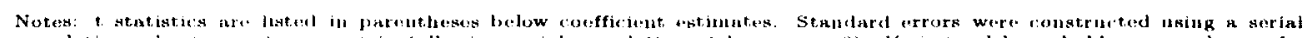

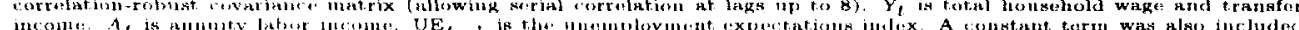

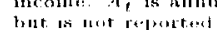

Table 2: Effects of Innovations on Nondurables Consumption

from the coefficient on actual current income growth in a regression of consumption growth on current income growth and the current innovations to annuity income. ${ }^{17}$ Table 2 presents the results when equation (1) is estimated using our two measures of annuity income.

The first regression shows that the lagged level of UE and the current innovation to our measure of annuity income are roughly equally important in explaining current consumption growth. The second regression shows that when the current innovation to UE is added to the equation, neither it nor the innovation to annuity income is individually statistically significant; however, the lagged level of UE remains important. The last two regressions show that, after controlling for unemployment expectations, the FRB-US measure of annuity income provides no further information about consumption growth at all.

In sum, the standard model of nondurable consumption growth, the Campbell-Mankiw model, implies that consumption growth should be related to two variables: income growth and the innovations to annuity income. Our empirical work shows that unemployment expectations are at least as important as either of these traditional variables in explaining nondurables consumption growth. Lagged balance sheet variables, on the other hand, are essentially uncorrelated with nondurable consumption growth once unemployment expectations are controlled for.

\footnotetext{
${ }^{17}$ This point relies heavily on the assumption that our estimate of annuity income growth correctly captures all the implications for annuity income of the innovation to current income. However, we do include current income growth among the variables used to construct annuity income, so in principle any such information is indeed included.
} 


\subsection{Balance Sheets and Spending on Durable Goods and Housing}

The standard CEQ PIH model described above applies to consumption of nondurable goods and services. However, as Mankiw (1982) showed, the model can be expanded to provide implications about durable goods spending if sufficient assumptions are made. In particular, if there are no transactions costs associated with durable goods purchases and if durable goods enter the utility function in a Cobb-Douglas manner, it is possible to show that the ratio of the stock of durable goods $Z_{t}$ to annuity income $A_{t}$ should be constant: ${ }^{18}$

$$
Z_{t}=\omega A_{t}
$$

Expenditure on durable goods in this case will be determined by two factors: the spending needed to counteract depreciation, and the spending required to adjust the stock of durable goods to any changes in the level of anmuity incone:

$$
\begin{aligned}
E_{t}^{\tilde{t}} & =Z_{t}-(1-\delta) Z_{t-1} \\
E_{\ell}^{z} / A_{t} & =\omega-(1-\delta) \omega A_{t-1} / A_{t} .
\end{aligned}
$$

Table 3 presents empirical results when we estimate an equation like (4) using US NIPA data on durables expenditures, augmented with $\mathrm{UE}_{t-1}$ and $\Delta \mathrm{UE}_{t}$. We also include: the ratio of current income to annuity income to allow some scope for current income to affect spending directly; the prime rate to allow a chammel for interest rates: and the ratio of net worth to annuity income (not shown in the table to save space; it was usually not statistically significant). We present results separately for our estimate of annuity income, the annuity income estimate based on the FRB-US methodology, and the analogous results where we use current income rather than an estimate of annuity income. ${ }^{19}$ Wo experimented with several methods of removing low-frequency movements or trends in the data, but they had little effect and are therefore not included ${ }^{20}$

\footnotetext{
${ }^{18}$ The assumption of frictionless adjustment is of course unattractive for durable goods, as many authors have pointed out. For an excellent discussion of the literature and of the difficulties, see Bertola and Caballero (1990), who also propose a sophisiticated (and complicated) method of estimating the process for durables expenditures under a generalized (S,s) model with fixed return points. See also Bertola and Caballero (1994) and Eberly (1997). For reasons that will become clear in the theoretical discussion below, however, these frameworks are not well suited to addressing the issues we are interested in here of the relationship between labor income uncertainty, balance sheet variables, and spending. We therefore adopt the approach of estimating as simple an empirical model as possible, with an eye to finding any correlations sufficiently robust that any theoretical model should be consistent with them.

${ }^{19}$ For the $Y_{t} / A_{t}$ variable, we use the ratio of current income to our estimate of annuity income.

${ }^{20}$ The Durbin-Watson statistics in the table indicate a large amount of positive serial correlation in durables spending Mankiw (1982) shows that in the model we nse the level of spending should follow a white noise process, and so the
} 
Ratio of Durables Consumption to Annuity Labor Income

1963:3-1994:3

\begin{tabular}{|l|c|c|c|c|c|c|c|}
\hline Annuity Income Measure & $A_{t-1} / A_{t}$ & Prime $_{t}$ & $\mathrm{UE}_{t-1}$ & $\Delta \mathrm{UE}_{t}$ & $Y_{t} / A_{t}$ & $\bar{R}^{2}$ & $\mathrm{D}-\mathrm{W}$ \\
\hline$A_{t}^{\text {O11r* }}$ & -0.213 & -0.115 & -2.326 & 0.702 & 0.219 & 0.44 & 0.55 \\
& $-(3.22)^{* * *}$ & $-(3.16)^{* * *}$ & $-(6.11)^{* * *}$ & $(1.03)$ & $(2.80)^{* * *}$ & & \\
\hline$A_{t}^{\text {FRB-US }}$ & 0.329 & -0.136 & -2.931 & -1.246 & 0.328 & 0.75 & 0.83 \\
& $(2.65)^{* *}$ & $-(4.97)^{* * *}$ & $-(9.35)^{* * *}$ & $-(2.07)^{* *}$ & $(10.40)^{* * *}$ & & \\
\hline$A_{t}=Y_{t}$ & -0.368 & -0.104 & -1.809 & 0.475 & 0.058 & 0.52 & 0.56 \\
& $-(3.24)^{* * *}$ & $-(2.71)^{* * *}$ & $-(3.73)^{* * *}$ & $(0.65)$ & $(0.73)$ & & \\
\hline
\end{tabular}

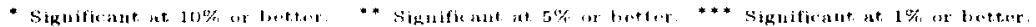

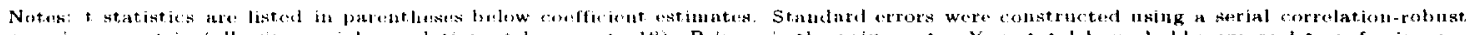

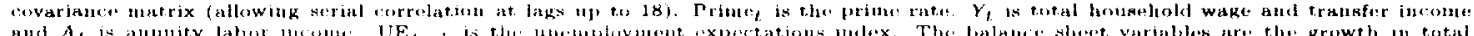

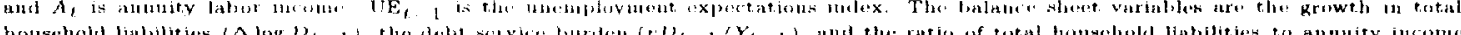

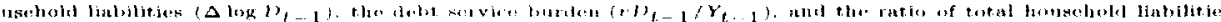

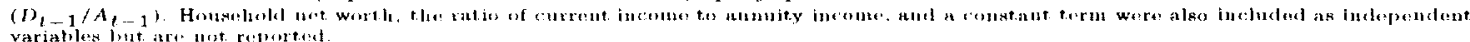

Table 3: Consumption of Durables, Baseline Equation

When the measure of annuity income is $A^{\text {Ours }}$ the annuity income ratio $A_{t-1} / A_{t}$ gets the correct (negative) sign (implying that growth in annuity income from $t-1$ to $t$ is associated with high durables purchases), as does the interest rate Prime, However, the lagged level of unemployment expectations is much more statistically significant than either ammuity income or interest rates. Once again, the change in unemployment expectations does not enter significantly. Finally, the ratio of current income to ammuity income, which plays no role in determining durables spending in the $\mathrm{CEQ}$ PIH model, is also highly significant in our regressions. This result differs from Bernanke (1984), who found in household data that transitory shocks to income had no effect on durables purchases. The discrepancy suggests either that our annuity income measures are imperfect or that consumers do in fact buy durables when they receive windfalls.

The second row of the table presents results when annuity income is measured using the FRB-US methodology. The main difference in results is that the annuity income ratio now receives the wrong sign. The last panel of the table shows the results when current income, rather than an estimate of annuity income, is used as a divisor. Results are generally similar to those for our measure of annuity income.

The top panel of the next table shows the results when our balance sheet variables are added to the baseline durables regression. ${ }^{21}$ The debt to annuity income ratio gets a negative and significant

empirical finding of severe serial correlation is inconsistent with the model. Caballero (1993) shows, however, that an $(\mathrm{S}, \mathrm{s})$ model implies precisely such slow adjustment. Because our theoretical model is essentially an expanded (S,s) model, Caballero's (1993) logic should apply to our nodel as well.

${ }^{21}$ For brevity, we report only the results for $A^{\text {(onrs. }}$. Conclusions are similar for $A^{\text {Frb-us }}$. 
Ratio of Durables Consumption to Amnuity Labor Income

\begin{tabular}{|c|c|c|c|c|c|c|c|c|}
\hline Row/Measure & $A_{t-1} / A_{t}$ & Prime $_{t}$ & $\mathrm{UE}_{t-1}$ & $\Delta \mathrm{UE}_{t}$ & $Y_{t} / A_{t}$ & $\begin{array}{c}\text { Balance } \\
\text { Sheet } \\
\text { Measure }\end{array}$ & $\bar{R}^{2}$ & D-W \\
\hline \multicolumn{9}{|c|}{ Entire Sample Period (1963:3-1994:3) } \\
\hline $1 \Delta \log D_{t-1}$ & $\begin{array}{c}-0.185 \\
-(3.13)^{* * *}\end{array}$ & $\begin{array}{c}-0.095 \\
-(2.95)^{* *} \\
\end{array}$ & $\begin{array}{c}-1.131 \\
-(2.45)^{* *} \\
\end{array}$ & $\begin{array}{c}0.790 \\
(1.28) \\
\end{array}$ & $\begin{array}{c}0.150 \\
(2.13)^{* *}\end{array}$ & $\begin{array}{c}0.377 \\
(4.22)^{* * *}\end{array}$ & 0.54 & 0.85 \\
\hline $2 r D_{t-1} / Y_{t-1}$ & $\begin{array}{c}-0.217 \\
-(3.22)^{* * *} \\
\end{array}$ & \begin{tabular}{|c|}
-0.103 \\
$-(3.54)^{* * *}$
\end{tabular} & $\begin{array}{c}-2.906 \\
-(6.97)^{* * *} \\
\end{array}$ & $\begin{array}{r}0.497 \\
(0.79)\end{array}$ & $\begin{array}{c}0.183 \\
(2.27)^{* *}\end{array}$ & $\begin{array}{c}0.413 \\
(2.94)^{* * *}\end{array}$ & 0.50 & 0.65 \\
\hline $3 D_{t-1} / A_{t-1}$ & $\begin{array}{c}-0.220 \\
-(3.46)^{* * *} \\
\end{array}$ & $\begin{array}{c}-0.115 \\
-(3.20)^{* * *} \\
\end{array}$ & $\begin{array}{c}-2.229 \\
-(6.57)^{* * *} \\
\end{array}$ & $\begin{array}{r}0.415 \\
(0.64) \\
\end{array}$ & $\begin{array}{c}0.299 \\
(5.13)^{* * *}\end{array}$ & \begin{tabular}{c|}
-0.027 \\
$-(2.64)^{* * *}$
\end{tabular} & 0.48 & 0.57 \\
\hline \multicolumn{9}{|c|}{ Before Financial Liberalization (1963:3-1980:1) } \\
\hline $4 \Delta \log D_{t-1}$ & $\begin{array}{c}-0.196 \\
-(4.22)^{* * *}\end{array}$ & $\begin{array}{r}-0.007 \\
-(0.31) \\
\end{array}$ & $\begin{array}{c}-2.025 \\
-(7.87)^{* * *} \\
\end{array}$ & $\begin{array}{r}-0.407 \\
-(0.95)\end{array}$ & $\begin{array}{c}0.236 \\
(7.79)^{* * *}\end{array}$ & $\begin{array}{c}0.180 \\
(3.91)^{* * *}\end{array}$ & 0.79 & 1.77 \\
\hline $5 r D_{t-1} / \overline{Y_{t-1}}$ & $\begin{array}{c}-0.189 \\
-(3.52)^{* * *}\end{array}$ & $\begin{array}{r}-0.017 \\
-(0.74)\end{array}$ & $\begin{array}{c}-2.527 \\
-(10.10)^{* * *}\end{array}$ & $\begin{array}{r}-0.682 \\
-(1.40)\end{array}$ & $\begin{array}{c}0.273 \\
(8.63)^{* * *}\end{array}$ & \begin{tabular}{c|}
0.010 \\
$(0.06)$
\end{tabular} & $0 . \overline{75}$ & 1.53 \\
\hline $6 D_{t-1} / A_{t-1}$ & $\begin{array}{c}-0.143 \\
-(2.62)^{* * *} \\
\end{array}$ & $\begin{array}{c}-0.106 \\
-(2.02)^{* *} \\
\end{array}$ & $\begin{array}{c}-2.098 \\
-(6.97)^{* * *} \\
\end{array}$ & $\begin{array}{r}-0.670 \\
-(1.45) \\
\end{array}$ & $\begin{array}{c}0.275 \\
(9.32)^{* * *}\end{array}$ & $\begin{array}{c}0.057 \\
(2.43)^{* *}\end{array}$ & 0.78 & 1.65 \\
\hline
\end{tabular}

Table 4: Consumption of Durables and Lagged Balance Sheet Variables

coefficient using our measure of annuity income. However. both lagged debt growth and the lagged debt service burden arc positive and significant for all three measures of income. Note that this is the opposite of what would be expected if precarious balance sheet conditions tend to deter consumers from spending. Instead, the regressions indicate that consumers tend to spend more on durable goods during periods when the debt service burden has been high or recent debt growth has been high. The obvious interpretation is that these results reflect a simultaneity problem: factors that cause consumers to be willing to spend heavily on durable goods also tend to make them willing to tolerate high debt service burdens or rapid debt growth or high ratios of debt to assets.

One specific hypothesis is that the simultaneity problem reflects the financial liberalization of the 1980s which may have allowed consumers to borrow more in order to purchase durable goods. If this explanation is correct, the statistical significance of the relationship between the durables spending share and balance sheet variables should have been much weaker in the period before financial liberalization. The bottom panel of the table therefore presents results for the same sets of regressions, but restricting the sample to the period before 1980. Evidence for the debt service burden is consistent 
with the liberalization hypothesis: it is insignificant during the earlier time period. The results for lagged debt growth also lend some support to the idea; although the variable remains highly statistically significant, the coefficient estimates for the pre-1980 period are about half of their values over the entire period. Finally, the debt to annuity income ratio now receives a positive and significant coefficient.

We now briefly examine the evidence on spending on what Saddam Hussein might call the mother of all durable goods: housing. Table 5 prosents regressions patterned on our durable goods regressions, but where the dependent variable is the number of homes sold per capita and the interest rate is the average rate on new mortgages. ${ }^{22}$ For the baseline regression specification, the results are remarkably similar (given the totally independent sources of data) to those for durables spending: Coefficient estimates on every variable are between two and four times the coefficient estimates in the durables regression, and the pattens of statistical significance are also very similar. Results for the balance sheet variables are also similar to those for the durables regressions, though more exaggerated, in that both lagged debt growth and the lagged debt service burden receive coefficients more than four times as large as in the durables regressions. However, the lagged debt to annuity income ratio, which received a negative and significant coefficient in our baseline durables regressions, is positive and significant here.

Our conclusion is that spending on durables and housing is very robustly correlated with lagged unemployment expectations. It is also highly correlated with our measure of annuity income growth, and with the ratio of current income to annuity income. However, with the exception of debt growth, durables spending is not robustly correlated with any balance sheet measure we examined ${ }^{23}$ Given the enormous changes in the US financial system over the period our data covers, and given the endogenous nature of balance sheet positions, it is perhaps not surprising that most balance sheet measures do not bear any stable relationship to spending. Indeed, the surprise may be that one balance sheet measure, debt growth, does seem to bear a relatively stable relationship to spending. We therefore turn now to an exploration of the determinants of debt growth.

\footnotetext{
${ }^{22}$ To save space in the table, we do not report the coefficient on a trend variable, which was highly statistically significant in all regressions. We obtained similar results with alternative methods of detrending. We also report results only for our measure of annuity income.

${ }^{23}$ This conclusion is consistent with recent work by Garner (1996), who found that most measures of the household debt burden do not Granger cause durable goods expenditures or GDP, and McCarthy (1997), who finds in a VAR framework that debt measures have little effect on subsequent nondurable or durable goods spending.
} 
Total Home Sales

1972:3-1990:1

\begin{tabular}{|c|c|c|c|c|c|c|c|c|}
\hline Row/Measure & $A_{t-1} / A_{t}$ & Mort $_{\ell}$ & $\mathrm{UE}_{t-1}$ & $\Delta \mathrm{UE}_{t}$ & $Y_{t} / A_{t}$ & $\begin{array}{c}\text { Balance } \\
\text { Sheet } \\
\text { Measure }\end{array}$ & $\bar{R}^{2}$ & D-W \\
\hline \multicolumn{9}{|c|}{ Annuity Income Constructed Using Our Method } \\
\hline 1 & $\begin{array}{c}-0.929 \\
-(3.48)^{* * * *}\end{array}$ & $\begin{array}{c}-0.698 \\
-(4.82)^{* * *}\end{array}$ & $\begin{array}{c}-7.471 \\
-(4.21)^{* * *}\end{array}$ & $\begin{array}{r}-1.541 \\
-(0.70)\end{array}$ & $\begin{array}{c}1.172 \\
(2.99)^{* * *}\end{array}$ & & 0.51 & 0.33 \\
\hline $2 \Delta \log D_{t-1}$ & $\begin{array}{c}-0.681 \\
-(2.79)^{* * *}\end{array}$ & $\begin{array}{c}-0.600 \\
-(4.82)^{* * *}\end{array}$ & $\begin{array}{r}-2.341 \\
-(1.27)\end{array}$ & $\begin{array}{r}-1.721 \\
-(0.77)\end{array}$ & $\begin{array}{c}0.784 \\
(2.54)^{* * *}\end{array}$ & $\begin{array}{c}1.306 \\
(3.78)^{* * *}\end{array}$ & 0.62 & 0.85 \\
\hline $3 r D_{t-1} / Y_{t-1}$ & $\begin{array}{c}-0.896 \\
-(3.21)^{* * *}\end{array}$ & $\begin{array}{c}-0.499 \\
-(2.23)^{* *}\end{array}$ & $\begin{array}{c}-8.962 \\
-(5.08)^{* * *}\end{array}$ & $\begin{array}{r}-2.834 \\
-(1.56)\end{array}$ & $\begin{array}{c}1.226 \\
(3.20)^{* * *}\end{array}$ & $\begin{array}{c}0.920 \\
(1.26)\end{array}$ & 0.51 & $\overline{0.34}$ \\
\hline $4 D_{t-1} / A_{t-1}$ & $\begin{array}{c}-0.709 \\
-(2.50)^{* *}\end{array}$ & $\begin{array}{c}-0.600 \\
-(4.84)^{* * *}\end{array}$ & $\begin{array}{c}-8.679 \\
-(4.66)^{* * *}\end{array}$ & $\begin{array}{c}-4.295 \\
-(2.38)^{* *}\end{array}$ & $\begin{array}{c}1.206 \\
(3.34)^{* * *}\end{array}$ & $\begin{array}{c}0.205 \\
(2.85)^{* * *}\end{array}$ & $0 . \overline{58}$ & $\overline{0.42}$ \\
\hline
\end{tabular}

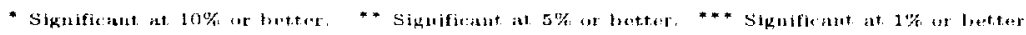

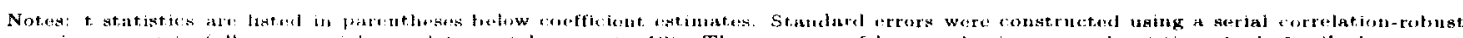

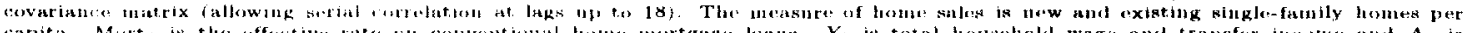

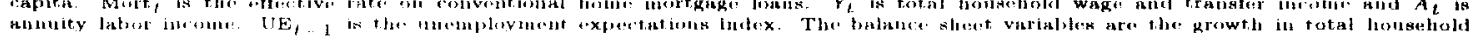

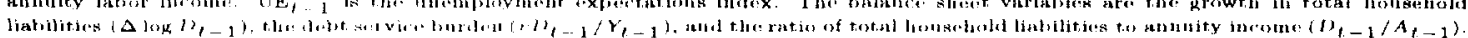

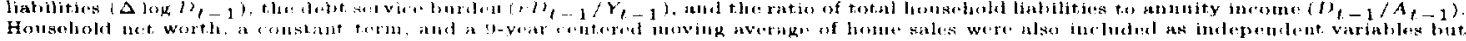
Homsoliold net. wint

Table 5: Total Home Sales

\subsection{The Cyclical Dynamics of Debt Growth}

Aside from the sharp increase in the debt ratio beginning in the mid-1980s, perhaps the most interesting feature of our Figuro 1 was that debt appears to exhibit a distinct cyclical pattern: its growth rate is much slower during recessions (the shaded regions of the chart) than during expansions.

It is a bit difficult to pin down the representative-agent CEQ PIH model's implications for debt, because the model does not distinguish debt from assets; aggregate net worth and human wealth are sufficient statistics for aggregate behavior. Of course, the vast majority of debt is associated with purchases of homes and other durable goods, so to the extent that our earlier empirical work captures the dynamies of home sales and durables purchases, the remaining interesting question to ask about debt growth is what else it is correlated with. The way we answer this question empirically is to see what variables are statistically significant explanators of debt growth once we control for contemporaneous home sales. The results are presented in Table 6.

As usual, the first variable we examine is lagged unemployment expectations; as usual, it is highly statistically significant and negative. Debt growth is also negatively correlated with the change in unemployment expectations, although (as usual) at a much lower level of statistical significance than the correlation with the lagged level. Again, a potential interpretation might be that the statistical significance of these variables owes to some correlation they have with the level of future income, 
Growth in Total Household Liabilities

Quarterly Data, 1968:2-1994:3

\begin{tabular}{|c|c|c|c|c|c|c|c|c|}
\hline Row/Measure & $H_{t}$ & $\mathrm{UE}_{t-1}$ & $\Delta \mathrm{UE}_{t}$ & $\Delta \log A_{t}^{0 u r m}$ & $\begin{array}{c}\text { Balance } \\
\text { Sheet } \\
\text { Measure }\end{array}$ & $\theta$ & SSR & D-W \\
\hline 1 & $\begin{array}{c}0.196 \\
(4.64)^{* * *}\end{array}$ & & & & & $\begin{array}{c}0.539 \\
(5.85)^{* * *}\end{array}$ & 0.59 & 2.46 \\
\hline$\overline{2}$ & $\begin{array}{c}0.140 \\
(5.79)^{* * *}\end{array}$ & $\begin{array}{c}-2.169 \\
-(5.72)^{* * *}\end{array}$ & & & & $\begin{array}{c}0.244 \\
(2.15)^{* *}\end{array}$ & 0.55 & 2.15 \\
\hline 3 & $\begin{array}{c}0.131 \\
(5.78)^{* * *}\end{array}$ & $\begin{array}{c}-2.864 \\
-(6.34)^{* * *} \\
\end{array}$ & $\begin{array}{c}-1.970 \\
-(3.90)^{* * *}\end{array}$ & & & $\begin{array}{c}0.306 \\
(2.72)^{* * *}\end{array}$ & 0.49 & 2.21 \\
\hline 4 & $\begin{array}{c}0.133 \\
(6.35)^{\cdots *}\end{array}$ & $\begin{array}{l}-2.536 \\
-(7.38)^{* * *}\end{array}$ & & $\begin{array}{c}0.180 \\
(3.90)^{* * *}\end{array}$ & & $\begin{array}{c}0.202 \\
(1.69)^{*}\end{array}$ & 0.51 & 2.12 \\
\hline 5 & $\begin{array}{c}0.130 \\
(5.90)^{* * *}\end{array}$ & $\begin{array}{c}-2.867 \\
-(6.41)^{* * *}\end{array}$ & $\begin{array}{c}-1.662 \\
-(2.42)^{* *}\end{array}$ & $\begin{array}{r}0.059 \\
(0.79) \\
\end{array}$ & & $\begin{array}{c}0.287 \\
(2.51)^{* * *}\end{array}$ & 0.49 & $2.1 \overline{9}$ \\
\hline $6 \Delta \log D_{t-1}$ & $\begin{array}{c}0.045 \\
(2.98)^{* * *}\end{array}$ & $\begin{array}{c}-1.385 \\
-(5.25)^{* * *}\end{array}$ & & & $\begin{array}{c}0.588 \\
(7.84)^{* * *}\end{array}$ & $\begin{array}{c}-0.443 \\
-(6.42)^{* * *}\end{array}$ & 0.48 & 2.07 \\
\hline $7 r D_{t-1} / Y_{t-1}$ & $\begin{array}{c}0.133 \\
(6.12)^{* * *}\end{array}$ & $\begin{array}{c}-2.345 \\
-(6.09)^{* * *}\end{array}$ & & & $\begin{array}{c}0.063 \\
(0.82)\end{array}$ & $\begin{array}{c}0.218 \\
(1.86)^{*}\end{array}$ & 0.54 & 2.13 \\
\hline $8 D_{t-1} / A_{t-1}$ & $\begin{array}{c}0.147 \\
(5.85)^{* * *}\end{array}$ & $\begin{array}{l}-2.063 \\
-(5.17)^{* * *}\end{array}$ & & & $\begin{array}{c}-0.004 \\
-(0.60)\end{array}$ & $\begin{array}{c}0.259 \\
(2.24)^{* *}\end{array}$ & 0.54 & 2.17 \\
\hline
\end{tabular}

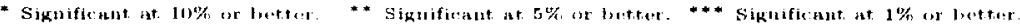

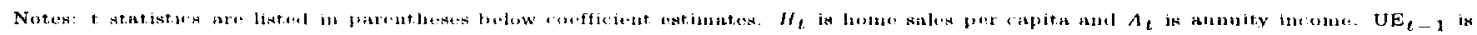

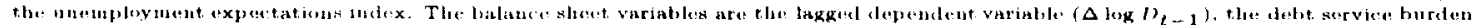

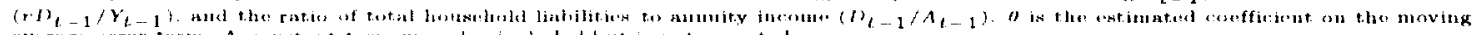

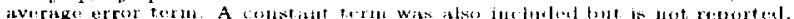

Table 6: Determinants of Debt Growth

but as in all our previous regressions when a measure of the change in annuity income is added to the equation the statistical significance of lagged unemployment expectations is unaffected (although the annuity income growth variable is also significant). Finally, debt growth is uncorrelated with the lagged values of our other two balance sheet variables but is significantly positively autocorrelated.

These regressions suggest that there is an independent channel for unemployment expectations in influencing debt growth, even beyond whatever effects unemployment expectations have on home sales. Because we found earlier that the pace of home sales is itself negatively influenced by unemployment expectations, in a sense these results imply that unemployment expecatations are doubly important for debt growth.

Implicit in our entire discussion up to this point has been an assumption that the pattern of debt over the business cycle is determined by consumers' unconstrained choices. An alternative possibility is that debt growth slows over the business cycle not because consumers desire to borrow less but because lenders restrict credit. A large literature now exists suggesting that lenders tighten credit standards to businesses during recessions. so that only "high quality" borrowers are able to borrow 


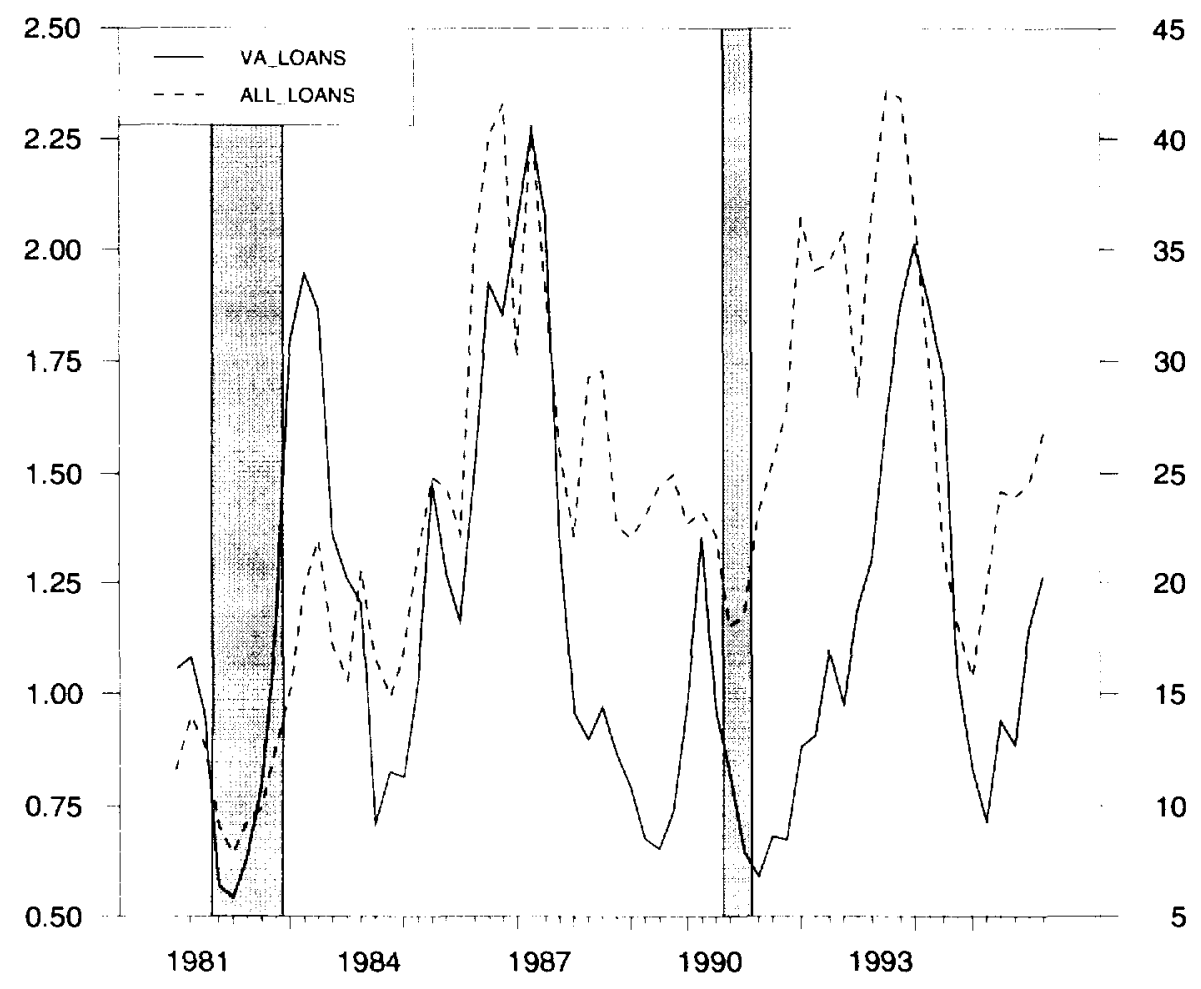

Figure 3: VA Originations and Total Mortgage Originations Over Trend GDP

freely in bad times; see Bernanke, Gertler, and Gilchrist (1996) for a survey. A recent paper by Bernanke, Ferri, and Simon (1997) presents evidence from the Federal Reserve's Survey of Consumer Finances suggesting that a similar phenomenon may affict consumers.

One way to identify demand and supply effects is to examine a form of mortgages for which there should be no cyclical effect on supply. The best candidate here is mortgages issued by the Veterans' Administration, because by law these mortgages are available to all qualified former military personnel. Because the government assumes the default risk, the supply of this form of mortgage financing should not fluctuate over the cycle even if lenders become more risk-averse in recessions. Indeed, because the government bears the risk on VA mortgages, one would expect to see a relative increase in the supply of VA mortgages. If the supply of other forms of credit does decline, we would also expect to see an increase in the relative demand for VA mortgages; hence any declines in VA mortgage issuance over the cycle probably underestimate the pure demand effect.

Figure 3 plots the number of VA mortgages originated in each quarter since 1981, together with total mortgages originated over the same period. There is clearly a strong correlation between VA 
mortgages and non-VA mortgages. Furthermore, during the two recessions in the sample, VA mortgages appear to fall, if anything, by more than non-VA mortgages. This evidence strongly suggests that demand factors very important role in fluctuations in mortgage borrowing over the business cycle.

This completes our discussion of the cyclical characteristics of consumption spending, home sales, and household balance sheets. We draw several conclusions. First, spending for nondurables, durables, and housing all generally respond to changes in annuity income (or at least our measure of annuity income) in the direction implied by the frictionless CEQ PIH model, although the magnitude of the response is generally not. nearly so large as the model would predict. Second, unemployment expectations typically seem to play at least as important a role as changes in annuity income in determining spending decisions. However, most of the information content of unemployment expectations variables is captured by the lagged level of unemployment expectations rather than by the change in unemployment expectations. Finally, the only measure of household balance sheet positions that is robustly correlated with spending appears to be the lagged growth rate of debt.

We turn now to the question of whether a model which incorporates a serious treatment of uncertainty, transactions costs, and liquid assets can explain the broad pattern of our empirical results.

\section{The Model}

\subsection{Theory}

The consumer's objective is to maximize expected discounted utility from consumption of housing services $Z$ and nonhousing goods $C$. The period utility function is CRRA in a Cobb-Douglas aggregate of utility from nonhousing consumption and the stock of housing:

$$
u\left(C_{t}, Z_{t}\right)=\frac{\left(C_{t}^{1-\alpha} Z_{t}^{\alpha}\right)^{1-\rho}}{(1-\rho)}
$$

There are five state variables which constrain or influence the consumer's choice of $C$ and $Z$ : the current stock of spendable resources $X_{t}$ (the sum of wealth and current labor income $Y_{t}$; or 'cashon-hand' in Deaton's (1991) terninology), the size of the home (if any) the consumer owns at the beginning of the period $H_{t}^{b}$; the level of the consumer's permanent labor income $P_{t}$; an indicator $I_{t}$ for the aggregate state of the economy; and the consumer's current employment (or Job) status

$J_{t}$. Note that we do not list mortgage debt as one of the state variables. This is because we make 
sufficient assumptions to guarantee that the ratio of the mortgage debt to home value is constant, thereby reducing the number of state variables in the problem by one. The necessary assumption is that the mortgage payment in each period contains a term that corresponds to the depreciation rate of the home. Hence the balance owed on the mortgage shrinks in each period by the same fraction that the value of the home shrinks.

The consumer's choices within each period are determined as follows (and as summarized in the table below). First the consumer makes a homeownership decision. If the consumer begins the period owning no house, $H_{t}^{b}=0$, the decision is whether or not to buy a house whose value we will denote $H_{t}^{e}=\phi P_{t}$, i.e. we assume that consumers must by a house whose value is equal to $\phi=3$ times their real after-tax permanent income. in accord with standard rules of thumb in the housing industry, see (1997). Buyers must also put up a down payment of amount $d=.2$ of the value of the house, and pay fees and taxes in amount $b=.03$. Renters purchase housing services in optimally chosen amount $Z_{t}$ at price $q \lambda$ where $\lambda$ is the flow cost of homeownership ${ }^{24}$ and the restriction $q=1.5>1$ gives consumers an incentive to buy. If the consumer begins the period as a homeowner they can sell the house and rent (implying $H_{t}^{\varepsilon}=0$ ), keep the house they currently own $\left(H_{t}^{e}=H_{t}^{b}\right)$, or sell the current house and buy a new one. For homeowners, the flow of housing services is equal to the size of the house $Z_{t}=H_{t}^{\epsilon}$.

Given our assumption that debt depreciates at the same rate as the house, the outstanding amount of debt will always be given by the amount $(1-d) H_{c}^{t}$. We assume that this debt must be serviced in each period by a fixed mortgage payment $m=\delta+r$ where $r=.02$ is the after-tax real rate of return and $\delta=.02$ is the depreciation rate of the house. The presence of the $\delta$ term in the mortgage payment represents the lender's compensation for the erosion in the real value of debt (this term can be thought of as roughly reflecting inflation).

Denoting the level of liquid assets that the consumer ends the period holding $S_{t}$, we can summarize the foregoing possibilites in the following table.

\footnotetext{
${ }^{24}$ Equal to the lost interest on the capital tied up in the house plus depreciation costs plus maintenance costs.
} 


\begin{tabular}{|c|c|c|c|c|}
\hline $\begin{array}{l}\text { Initial } \\
\text { Status }\end{array}$ & $\begin{array}{c}\text { Period } t \\
\text { Action(s) }\end{array}$ & $S_{t}$ & $H_{t}^{e}$ & $Z_{t}$ \\
\hline$H_{t}^{b}=0$ & Keep Renting & $\overline{X_{t}-C_{t}-q \lambda Z_{t}}$ & 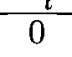 & Optimal \\
\hline$H_{t}^{b}=0$ & Buy & $X_{t}-C_{t}-(d+b) H_{t}^{e}-[m(1-d)+n] H_{t}^{e}$ & $\phi P_{t}$ & $H_{t}^{e}$ \\
\hline$H_{t}^{b}>0$ & Sell and Rent & $X_{t}-C_{t}+(d-b) H_{t}^{b}-q \lambda Z_{t}$ & 0 & Optimal \\
\hline$H_{t}^{b}>0$ & Hold & $X_{t}-C_{t}-[m(1-d)+n] H_{t}^{c}$ & $H_{t}^{b}$ & $H_{t}^{e}$ \\
\hline$H_{t}^{b}>0$ & Sell and Buy & $\begin{array}{c}X_{t}-C_{t}+(d-b) H_{t}^{b}-(d+b) H_{t}^{e} \\
-[m(1-d)+n] H_{t}^{e}\end{array}$ & $\phi P_{t}$ & $H_{t}^{e}$ \\
\hline
\end{tabular}

We are now in position to write down the consumer's optimization problem. The consumer of course has no influence over the aggregate state; furthermore, for simplicity we assume that the consumer's job status and permanent income also evolve exogenously. Hence the control variables potentially available to the consumer are three: $C, H^{e}$, and $Z$. The Bellman equation is therefore:

$$
\begin{aligned}
& V_{t}\left(X_{t}, H_{t}^{b}, I_{t}, J_{t}, P_{t}\right)= \\
& \quad \max _{\left\{C_{,}, Z_{t}, H_{t}^{\prime}\right\}} u\left(C_{t}, Z_{t}\right)+\beta E_{t} V_{t+1}\left(X_{t+1}, H_{t+1}^{b}, I_{t+1}, J_{t+1}, P_{t+1}\right)
\end{aligned}
$$

The level of permanent labor income is assumed to follow a first-order Markov process with drift parameter $G_{t+1}$ :

$$
P_{t+1}=G_{t+1} P_{t} \Pi_{t+1}
$$

where $\Pi_{t+1}$ is a stochastic shock to permanent labor income, and $G_{t+1}$ is the mean growth rate for the permanent income of employed consumers given the aggregate state that prevails in period $t+1$. With this process for permanent labor income, along with the fact that the utility function is homogeneous of degree zero, ${ }^{25}$ it is possible to rewrite the problem in terms of ratios of $C, Z, X$, and $H^{b}$ to permanent labor income, thus effectively reducing the number of state variables to four. Specifically, defining $c_{t}=C_{t} / P_{t}$ and $z_{t}, x_{t}$, and $h_{t}^{b}$ similarly, the problem can be written as:

$$
\begin{aligned}
& v_{t}\left(x_{t}, h_{t}^{b}, I_{t}, J_{t}\right)= \\
& \underset{\substack{\left.\max _{t}, z_{t}, h_{t}\right\} \\
\text { max }}}{ } u\left(c_{t}, z_{t}\right)+\beta E_{t}\left(G_{t+1} \Pi_{t+1}\right)^{1-\rho} v_{t+1}\left(x_{t+1}, h_{t+1}^{b}, I_{t+1}, J_{t+1}\right)
\end{aligned}
$$

\footnotetext{
${ }^{25}$ Plus certain conditions that must be (and are) satisfied by the constraints.
} 
We assume that the level of actual labor income in period $t$ is given by the level of permanent labor income multiplied by a transitory shock $\Psi_{t}$ :

$$
Y_{t}=P_{t} \Psi_{t}
$$

The consumer's decisions within the period determine the size of the housing stock at the end of the period $H_{t}^{e}$ and the amount of liquid assets (or savings) on hand at the end of the period $S_{t}$ subject to a liquidity constraint that requires $S_{t} \geq 0$. Given $H_{t}$ and $S_{t}$, the levels of beginning-of-period housing $H^{b}$ and cash-on-hand in period $t+1$ are given by:

$$
\begin{aligned}
& H_{t+1}^{b}=(1-\delta) H_{t}^{e} \\
& X_{t+1}=R S_{t}+Y_{t+1}
\end{aligned}
$$

where $R=1.02$ is the annual gross interest rate between periods. Dividing both sides of both of these equations by $P_{t+1}$ and substituting from the permanent labor income equation (6) yields:

$$
\begin{aligned}
h_{t+1}^{b} & =\frac{h_{t}^{e}(1-\delta)}{G_{t+1} \Pi_{t+1}} \\
x_{t+1} & =\frac{R}{G_{t+1} \Pi_{t+1}} s_{t}+\Psi_{t+1}
\end{aligned}
$$

\subsection{The Aggregate State}

Following the work of Sichel $(1993,1994)$ we assume that the aggregate economy has three states:

\begin{tabular}{|c|c|c|c|c|}
\hline & & \multicolumn{3}{|c|}{ Period $t+1$ Aggregate State } \\
\hline & & Expansion & Contraction & Recovery \\
\hline Period $t$ & Expansion & 0.95 & 0.05 & 0 \\
\hline Aggregate & Contraction & 0.05 & 0.70 & 0.25 \\
\hline State & Recovery & 0.25 & 0.05 & 0.70 \\
\hline
\end{tabular}
recessions, which are characterized by high jobloss risk and low aggregate growth; booms, which are characterized by low jobloss risk and high aggregate growth; and recoveries, which always follow recessions and which exhibit high growth but continuing high jobloss risk. ${ }^{26}$ Transitions between these states are governed by the following Markov transition matrix:

\footnotetext{
${ }^{26}$ 'The 'recovery' phase allows our model to capture the fact that the unemployment rate typically remains higher than average for an extended period after the NBER trough.
} 
where the switching probabilities were chosen to match the empirical fraction of the time the economy has spent in expansion versus contraction in the postwar US, and the probabilities for the 'recovery' period were chosen so that recoveries would last for four quarters on average, and the probability of slipping from recovery back into recession is the same as the probability of entering a recession from an expansion.

\subsection{The Household Income Process}

\subsubsection{The Employment State}

Unemployment spells last one or two periods, and when consumers lose their jobs they know whether the spell will be a one or a two period spell (we chose this structure to allow average spell length to be longer during recessions than during expansions). Consumers in the last period of an unemployment spell face the same employment hazards as employed consumers; thus a very unlucky consumer could experience two (or even more) unemployment spells in a row. Designating status "employed" as $E$, unemployed with one remaining quarter of unemployment as $U_{1}$ and unemployed with two quarters remaining as quarter as $U_{2}$ we assume the employmont state transition matrix in expansions is:

\begin{tabular}{c|cccc} 
& \multicolumn{4}{|c}{ Period $t+1$ Status } \\
\hline Period & & $E$ & $U_{1}$ & $U_{2}$ \\
$t$ & $E$ & 0.97 & 0.01 & 0.02 \\
Status & $U_{1}$ & 0.97 & 0.01 & 0.02 \\
& $U_{2}$ & 0 & 1 & 0
\end{tabular}

while we assume that in contractions and recoveries the matrix is:

\begin{tabular}{c|cccc} 
& \multicolumn{4}{|c}{ Period $t+1$ Status } \\
\hline Period & & $E$ & $U_{1}$ & $U_{2}$ \\
$t$ & $E$ & 0.96 & 0 & 0.04 \\
Status & $U_{1}$ & 0.96 & 0 & 0.04 \\
& $U_{2}$ & 0 & 1 & 0
\end{tabular}

where the transition probabilities were chosen to generate steady-state unemployment rates around 5 percent in expansions and 8 percent in contractions and recoveries (by "steady-state" we mean the rate that would eventually prevail if the economy remained in the expansion, or contraction, or recovery for many periods).

\subsubsection{The Transitory Shocks}

Transitory shocks to income are drawn for all employed consumers in each period from a three point symmetric distribution with mean one and equal probability mass on each of the three possible draws. Thus the possible draws are $\left(1-\nu^{\prime}, 1,1+\nu^{e}\right)$ in expansions and $\left(1-\nu^{\mathrm{cr}}, 1,1+\nu^{\mathrm{cr}}\right)$ in contractions 
and recoveries, $\nu^{c r} \geq \nu^{*}$ (in practice we assume transitory shocks are of equal size in all aggregate states, $\nu^{c r}=\nu^{e}=.1$ ). Unemployed consumers receive unemployment compensation in amount $\underline{Y} P_{t}$ with certainty, where we assume that the replacement rate $\underline{Y}=.5$ does not vary with the cycle.

\subsection{The Permanent Shocks}

For employed consumers. permanent shocks to income, like transitory shocks, are drawn in each quarter from a three point symmetric distribution with mean one and equal probability mass on each of the three possible draws. We assume the three possibilities are $(0.95,1.00,1.05)$ in all three aggregate states, which amounts to a conservative estimate given that microeconomic studies typically estimate that the standard deviation of the annual innovation to permanent income is at least 10 percent annually (see Carroll (1992) for a brief survey). We assume that unemployment spells in all three states of the economy typically end with consumers taking jobs at a level of permanent income that is on average 10 percent lower than the permanent income associated with their previous job (this is one of the few statistics we were able to calibrate using existing data from the labor economics literature; see, e.g., Carrington (1993) for evidence on the typical size of wage losses). However, we were unable to find evidence on how this statistic varies over the business cycle, so we assume that it is the same in all three aggregate states. We again assume a three point symmetric distribution with equal probability weights on all three outcomes, but we assume that the shock process during contractions and recoveries is a mean preserving spread of the shock process during expansions. Specifically, the possible outcomes are $(0.8,0.9,1.0)$ in booms and $(0.7,0.9,1.1)$ in contractions and recoveries.

\subsection{Summary}

Although the model can be solved for quite general combinations of parameter values, we have intentionally kept the structure of uncertainty simple in order to make the model easier to understand and analyze. In our parameterization, the only differences in risk between aggregate states come from the fact that in recessions and recoveries unemployment spells are more likely, last longer, and are associated with larger permanent income shocks. The processes for transitory and permanent shocks for employed consumers are the same in all three aggregate states, as is the mean of the distribution for permanent shocks for the unemployed. Many of these parameters could in principle be calibrated using microeconomic data, but we were not able to find many existing studies that were useful for 
that purpose.

\subsection{A Wish List}

In order to solve the model, we had to make a variety of simplifying assumptions. Even so, the full version of the model used for analysis of the effects of financial market deregulation has six state variables: the four described above $\left(x_{t}, h_{t}^{b}, I_{t}, J_{t}\right)$ plus the current value of the down payment ratio $d$ required for new home purchases and the value of the down payment ratio that prevailed when the consumer took out their mortgage loan. The full model takes our new Unix workstation four days to solve and another two to simulate, so substantially relaxing the simplifying assumptions is not feasible with present technology. It is nevertheless worthwhile to draw attention to the assumptions we would most like to relax as technology advances. First is the assumption that the level of debt is perfectly correlated with the level of the housing stock. We would have preferred to make assumptions that guaranteed at least a modest buildup of home equity over the course of time. The second assumption we would like to relax is that there is no house price risk. Although Fratantoni (1996) found that the effects of this kind of risk were small compared to the effective risk caused by the fixed mortgage commitment, it would be useful to see whether that result carries over into this context. This assumption could obviously interact with the first assumption because house price risk could put some consuniers 'under' water,' holding a mortgage whose value exceeds that of the house. Finally, we would like to allow consumers to choose the size of the new house they buy. However, we suspect that this last change would not affect bellavior nuuch: because consumers will live in their house for an average of ten years, it seens unlikely that transitory factors such as the current aggregate state should optimally have much effect on the optimal size of house to buy.

\subsection{Solution}

As anyone familiar with the recent literature on consumption under uncertainty would anticipate, solution of this model was a major challenge. A short companion paper (1997) briefly describes our solution method, which involves numerical iteration on the value function. Carroll and Kimball (1996) have shown that even in the simpler case where there is only a single, nondurable, consumption good, the consumption policy rule is strictly concave (and therefore presumably not analytically soluble) whenever utility is of the Hyperbolic Absolute: Risk Aversion (HARA) form (a class that subsumes 
Constant Absolute Risk Aversion (CARA). Constant Relative Risk Aversion (CRRA), and StoneGeary versions of CARA and CRRA utility) and there is both labor income and rate-of-return risk. That paper shows that there are only three degenerate cases which yield linear consumption rules: quadratic utility. Constant Absolute Risk Aversion utility with only labor income risk, and Constant Relative Risk Aversion with only ratc-of-return risk. Given the lack of analytical solutions to even the simpler problem for nondurable consumption, the resort to numerical methods was inescapable here - even if the fixed transactions costs did not add major further complications.

Previous work on $(\mathrm{S}, \mathrm{s})$ models has either assumed assumed risk neutrality of consumers (Bertola and Caballero $(1990)$ ) or has assumed that the only risk consumers face is rate-of-return risk (Grossman and LaRoque (1990), Eberly (1997)) in order to exploit the linearity of the optimal consumption rule under power utility (which, under certain further assumptions, implies a closed form solution to even the more complicated (S,s) problem). A very recent paper by Caplin and Leahy (1997) makes substantial progress in deriving empirical implications of a model in which the marginal utility of wealth does not vary over the business cycle (except as a result of interest rate fluctuations). While these assumptions are defensible for many purposes, they are obviously unacceptable in a study of the effects of labor income uncertainty on durables purchases.

Despite the mathematical difficulty of solving the model, the behavior of consumers in this model can be described reasonably simply. Most of the time they are homeowners, because ownership is cheaper than renting. During most of the time that they are homeowners, they engage in "bufferstock saving," in which they try to maintain a target level of liquid precautionary assets which they use to smooth nonhousing consumption in the face of income shocks (see Deaton (1991) and Carroll (1992, 1997) for detailed analysis of buffer-stock saving behavior in a model with only nondurable goods). As the time approaches to buy a new home, however, they engage in a bit of extra saving in order to accumulate the required downpayment.

The homeownership decision can be described as following a modified (S,s) rule. Because the value of the house depreciates over time, and because permanent labor income grows, the ratio of home value to permanent labor income drifts down over time. When this ratio drops far enough the consumer sells the existing home and buys a new one. The most important twist in this model, relative to the standard $(\mathrm{S}, \mathrm{s})$ model of durable goods, is that the precise trigger point at which the consumer 


\section{Trigger}

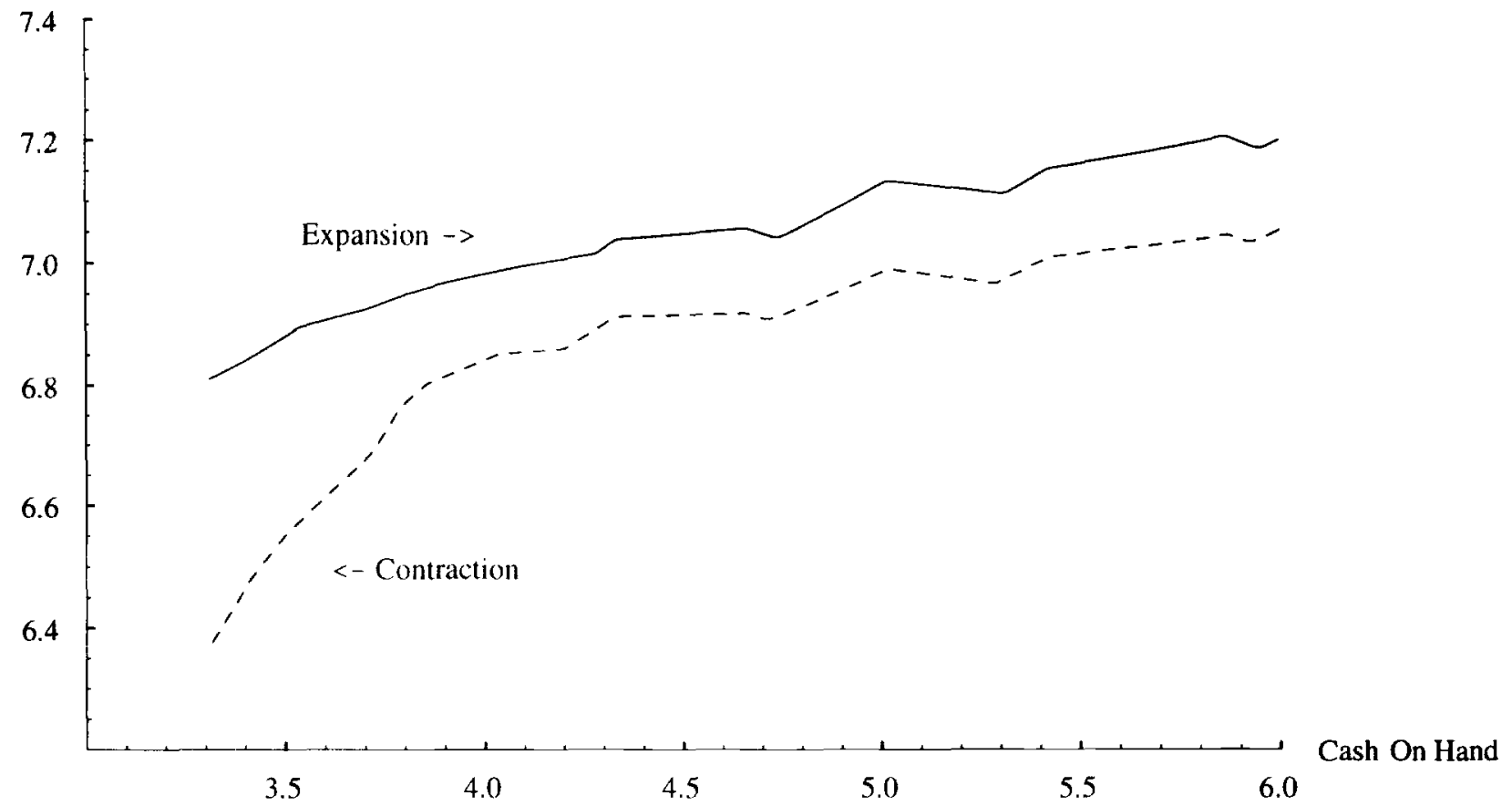

Figure 4: The Jump in the Lower (S,s) Trigger

decides to buy a new house depends on both the anticipated risk of unemployment and the size of the consumer's current buffer stock of liquid assets. This is illustrated by Figure 4, which shows the lower trigger point of the (S,s) rule as a function of the level of liquid assets the consumer has, for an employed consumer living in an economy in an expansion. ${ }^{27}$ The curve is upward sloping, indicating that consumers with more liquid assets will buy a new durable carlier (or, more formally, at a higher trigger value). Note that, in the presence of aggregate shocks to transitory income, this result could rationalize our empirical finding that durables and home sales are high in periods of high "transitory" income. That is, when they receive windfall income, some consumers are pushed rightward across the $(\mathrm{S}, \mathrm{s})$ barrier. This is an interesting theoretical difference with the CEQ model as explored, for example, by Bernanke (1985), in which transitory shocks to income should have essentially no effect on durable goods spending. ${ }^{2 \gamma}$

\footnotetext{
${ }^{27}$ We also assume that the consumer bought his current house with an 80 percent mortgage and expects to finance the new house with an 80 percent mortgage.

${ }^{28}$ One way to think about this finding is as an increase in the 'marginal propensity to consume' durable goods out of transitory income. As a theoretical matter, this result corresponds closely to Kimball's (1990) finding that precautionary saving boosts the marginal propensity to consume nondurables out of transitory income.
} 
The figure also shows (the dashing line) how the trigger locus changes if the economy enters a recession: for any given level of licpuid assets, the trigger point is lower (consumers will put up with living in a poorer house rather than buy). That is, a consumer who had been on the brink of home purchase before the econony entered the recession will now wait until the house has depreciated more before buying. Alternatively, a consumer with a given house value will require a larger stock of precautionary liquid assets before he will be willing to buy. This shift in the lower $(\mathrm{S}, \mathrm{s})$ trigger is what we refer to in the title of the paper as "Jumping $(\mathrm{S}, \mathrm{s})$ Triggers."

The foregoing story is somewhat different from the standard (S.s) model's explanation of durables purchases over the business cycle found in, for example, Bar-Ilan and Blinder (1992) or Bertola and Caballero (1990) or Caplin and Leahy (1997).$^{29}$ The main difference is the explicit importance of cyclical variation in labor income uncertainty in our model; in the standard model, the sharp drop in durables purchases in recessions is triggered, not by an increase in uncertainty, but by a decrease in the level of expected future income and thus of 'permanent income' as they define it. The empirical distinction between the two models is thus that our model would imply a strong effect of uncertainty per se on durables purchases, even after controlling for permanent (or annuity) income. Another way to interpret the jump in the trigger is as reflecting the fact that an increase in uncertainty causes an increase in the marginal utility of liquid wealth, because its value as a buffer-stock against uncertainty rises. This is in explicit contrast with Caplin and Leahy's assumption that the marginal utility of wealth is constant ${ }^{30}$

For purposes of cyclical anlaysis, the most important implication of the model comes from the interaction of the precautionary saving motive and the jumping $(\mathrm{S}, \mathrm{s})$ bands. When the economy switches into a recession, a large proportion of the entire set of consumers who had been on the brink of home purchase suddenly feel that their current stock of precautionary saving, which had been adequate when they anticipated continued prosperity, is inadequate in the new, riskier environment. These consumers postpone their home purchases until they have accumulated enough additional pre-

\footnotetext{
${ }^{29}$ One interesting recent paper that adopts a rather different approach to these issues is Greenspan and Cohen (1997), who model vehicle sales as a function of "scrappage" and who make a distinction between "engineering scrappage" and "cyclical scrappage." Roughly speaking, however, it is possible to interpret the effects of the jumping (S,s) trigger in our model as corresponding to the "cyclical scrappage" term in the Greenspan and Cohen model.

${ }^{30}$ One recent paper which focuses on the effects of jumping (S,s) triggers is Adda and Cooper (1997), who examine the effects of two natural experiments thoughtfully provided to economists by the French government. The experiments involved subsidies to automobile scrappage, which should have had the effect of moving the lower (S,s) trigger up. Adda and Cooper document that the reaction of automobile sales to the tax subsidies was quite similar to the predictions of an $(\mathrm{S}, \mathrm{s})$ model when the: lower trigger moves up.
} 
cautionary savings to again feel comfortable with the home purchase decision (or until their home has deteriorated so much that they are willing to risk buying a new one even with a low buffer-stock of liquid assets). ${ }^{31}$

Another interesting feature of this model that is not present in the standard model is that home equity serves as an additional reserve of emergency precautionary resources beyond liquid assets. Consumers who experience a particularly vicious series of income shocks can, in the last resort, sell their houses in order to tap the equity to finance current consumption. Of course, they pay a heavy price for this; they must incur brokerage fees and pay for rented housing services at a price substantially higher than the user cost of ownership. Still, extreme circumstances call for extreme measures. This feature of the model is interesting because several papers in the empirical literature on precautionary saving have found larger effects of uncertainty on net worth than on liquid assets. Carroll and Samwick (1997) speculate that the reason may be precisely this potential use of home equity as a precautionary reserve.

Our paper is not the first to argue that variations in the degree of uncertainty are important in explaining durables purchases over the business cycle. As Bernanke (1983) pointed out, and many authors have emphasized since, an increase in uncertainty increases the 'option value' of waiting until the uncertainty is resolved. ${ }^{32}$ A formal illustration of this can be seen in Eberly (1997); she shows that in a model with only rate-of-return risk, when the degree of rate-of-return risk goes up the $(\mathrm{S}, \mathrm{s})$ bands widen, provoking a response similar to that of the jump in the $(\mathrm{S}, \mathrm{s})$ band we depict. However, the underlying cause of the jump is rather different. In Eberly's model the primary reason for the shift in the (S,s) bands is that if the bands did not change, an increase in uncertainty would increase the expected present discounted value of the adjustment costs the consumer would have to pay. Thus the effect of uncertainty in her model has little to do with precautionary behavior - instead, it mainly reflects a change in the tradeoff between minimizing average fixed costs and minimizing average distance from the optimal housing stock. Again, a useful way to understand the difference between the models is to realize that the main effect driving the jump in the $(\mathrm{S}, \mathrm{s})$ trigger in our model

\footnotetext{
${ }^{31}$ In the Greenspan/Cohen model, the implication would be that "cyclical scrappage" is strongly related to unemployment expectations. Although Greenspan and Cohen do not report regressions of cyclical scrappage on unemployment expectations, they do report that cyclical scrappage falls when the unemployment rate rises, which is roughly what one would expect from our model.

${ }^{32}$ For a thorough and recent treatment, see Dixit and Pindyck (1994).
} 
is an increase in the marginal utility of liquid assets - an effect that is absent in the Bernanke and Eberly models.

An even earlier analysis of many of these issues can be found in three insightful articles by Frederick Mishkin $(1977,1976,1978)$ which anticipate many (though not all) of the theoretical results that come from our formal optimizing model. In particular, Mishkin (1978) argues that "A consumer suffering financial distress, and unable to pay his bills readily, would prefer holding highly liquid financial assets. This implies that as the consumer perceives an increasing probability of financial distress, he will decrease his demand for consumer durables and limit his purchases." Using an intuitive but ad-hoc functional form, Mishkin also documents a strong correlation between durables purchases and consumer sentiment, and explicitly interprets consumer sentiment as a measure of uncertainty.

\section{Simulation Results}

\subsubsection{A Stylized Business Cycle}

Our simulation results examine the aggregate characteristics of an economy populated by 20,000 consumers behaving according to the optimal decision rules that solve the maximization problem in Section 3. As preparation for the simulations, we start the model economy off at an essentially arbitrary point, then simulate for 400 quarters of expansion. by which time it has settled into a stochastic steady-state with a reasonably settled distribution of consumers across the state space.

The first experiment we perform is to examine a recession of typical length (four quarters) followed by recovery period of the same length. We show the path of aggregate variables from 8 quarters before the begimning of the reccssion to four quarters after the end of the recovery. Results are shown in Figures 5 and 6; the contraction is shaded dark gray and the recovery period is shaded light gray. In the first quarter of the recession. the unemployment rate begins moving up as the new, higher job loss risk affects its first batch of victims. Recall, however, that unemployment spells in recessions last two quarters; this means that the new recessionary equilibrium level of the unemployment rate is only reached in the second quarter of recession. Thereafter the unemployment rate stays at the same high level throughout the recession and recovery periods, reverting to its expansionary level only in the second quarter after the ond of the recovery period.

The adjacent chart shows the expecterl risk of job loss over the next four quarters for a currently 

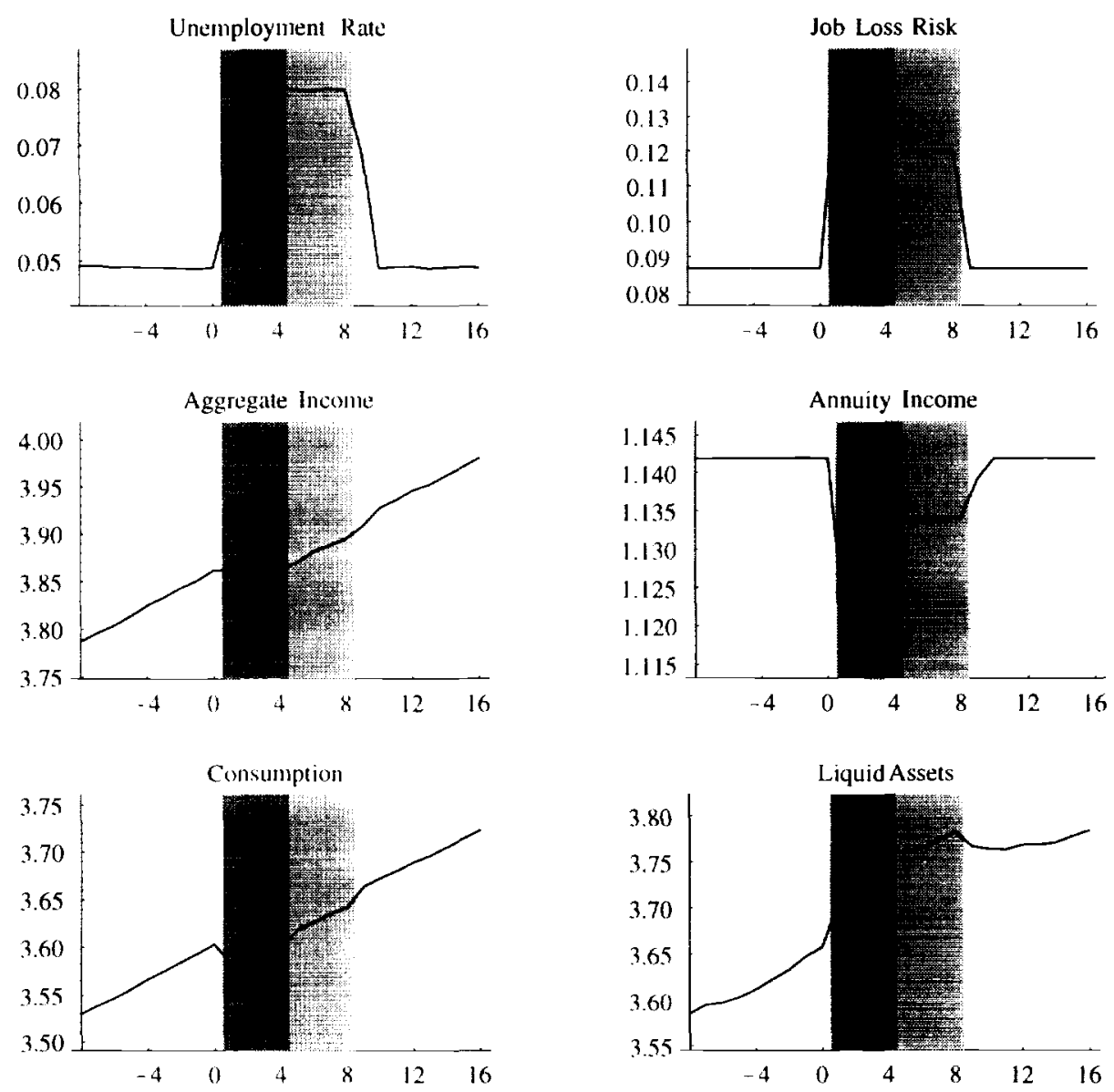

Figure 5: A Typical Recession In Our Simulated Economy

employed consumer, a statistic: we take to be the closest analogue in our model to the unemployment expectations variable used in our empirical work. Because it is an expectational variable, when the economy enters a recession this measure jumps immediately to its recessionary steady-state value. When the economy noves into the recovery phase expected job loss risk drops because consumers know that it is likely that the economy will enter an expansionary phase in the near future.

Aggregate income is given by simply summing the actual current labor income of all the households we are simulating. Movements in aggregate income can therefore be decomposed into those due to changes in the level of permanent labor income and those due to transitory shocks. The adjoining figure shows annuity income. calculated as defined in the empirical section as the annuity value of the present discounted value of future labor income. We calculate aggregate annuity income in our model from the combination of the transition matrix for aggregate states and the transition matrices 
for employment states during each aggregate state. In calculating annuity income we abstract from the long-term secular growth in income; results would have been essentially the same had we allowed the drift term to enter.

Nondurables consumption, which is determined (as always) in large part by expectations, drops immediately and sharply when the economy enters a recession. Consumption recovers somewhat when the economy enters the recovery phase and further when the economy enters the expansionary phase. The final figure in the set shows the behavior of liquid assets, which rise sharply during the recession because households feel the need to boost the level of their precautionary buffer-stocks. Note that the precautionary motive is intense enough to outweigh the dissaving being done by the unemployed consumers. Savings level off during the recovery period and remain flat when the expansion begins.

The next set of figures shows the evolution of the housing market and household balance sheets. In the first two quarters of the recession, home sales plummet for the reasons described above: newly wary consumers want a higher level of precautionary liquid assets before buying a house. Note the impressive magnitude of the initial decline in home sales: the rate of sales per capita falls by roughly 50 percent. After the initial collapse. home sales begin to rise again, then show a minor surge when the economy enters the recovery plase. Finally, when the economy switches into expansion there is a massive surge of home sales as the consumers who had been postponing purchases for precautionary reasons throw caution to the wind.

This last phenomenon, the surge of sales when the economy exits the contraction, has a natural interpretation as the release of "pent-up demand." "Pent-up demand" is a phrase used loosely by analysts of the housing and auto sectors who claim that recessions are periods when "pent-up demand" rises, only to be 'released' when the economy emerges from the contraction. Pent-up demand could be defined rigorously in our model as the demand which would be immediately be expressed in purchases if consumer expectations returned to normal levels. In other words, pent-up demand corresponds to the set of consumers populating the region of the (S.s) diagram between the jumping loci of the lower $(\mathrm{S}, \mathrm{s})$ band..$^{33}$

It is worth noting just how close the correspondence is between this phenomenon in the formal

${ }^{33}$ This definition differs somewhat from the definition proposed by Caballero and Engel (1994). They investigate a model with fixed $(S, s)$ bands and describe a period of high pent-up demand as a period with a heavier than usual concentration of agents near the (unmoving) trigger point. 

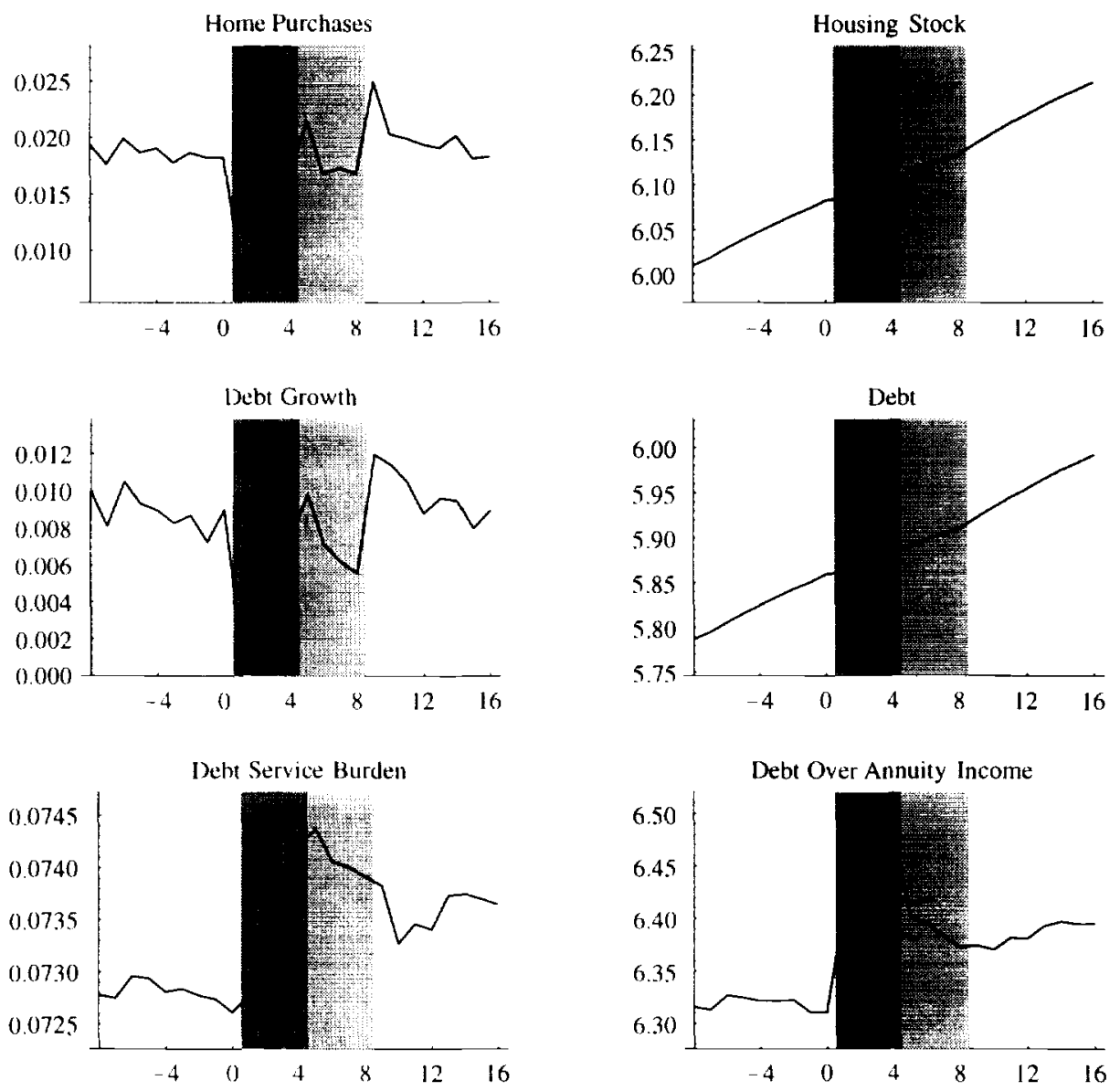

Figure 6: The Housing Market and Balance Sheets

model and the informal descriptions of industry analysts in both the housing and the automotive markets. For example, a May 11, 1992 editorial (p. 12) in Automotive News read, in part: "[F]olks still aren't buying cars ... and 1 am convinced that most Americans are still concerned about their jobs. As long as that insecurity exists, we are going to see a sluggish auto industry."

The figure adjacent to the home sales figure shows the obvious implication of sales for the level of the housing stock: at the onset of a recession, the growth rate of the housing stock decelerates. Below are the growth rate of debt and the time path of the debt stock, which strongly resemble the patterns of home purchases and the housing stock.

The final two figures show the behavior of our measures of household balance sheet conditions over the business cycle. Both the debt service burden and the ratio of debt to annuity income rise sharply at the beginning of the recession, in both cases because the numerator is largely fixed by past 
decisions while the denominator (income or annuity income) falls when the economy enters a recession. Thereafter the debt service burden drifts until the economy enters a full expansionary phase again, while the ratio of debt to annuity income drops as soon as the economy enters the recovery period (because the level of annuity income jumps up; see the previous set of figures).

\section{Comparing the Model to US Cyclical Data}

We turn now to some simulations based on the pattern of expansion and contraction for the US economy since 1961, roughly the period for which we were able to perform our empirical work on US NIPA data. Again we start the economy off from the steady-state equilibrium achieved after 400 quarters of continuous expansion, lut for quarters 401 through 539 (corresponding to 1962Q2 through 1995Q4) we set the aggregate state of the simulated economy equal to the aggregate state of the corresponding quarter for the US economy as indicated by the official NBER chronology. (We arbitrarily assume that every recession is followed by a recovery period that is four quarters long, which is the expected duration implied by the transition matrix.) The next set of figures shows the results graphically. 

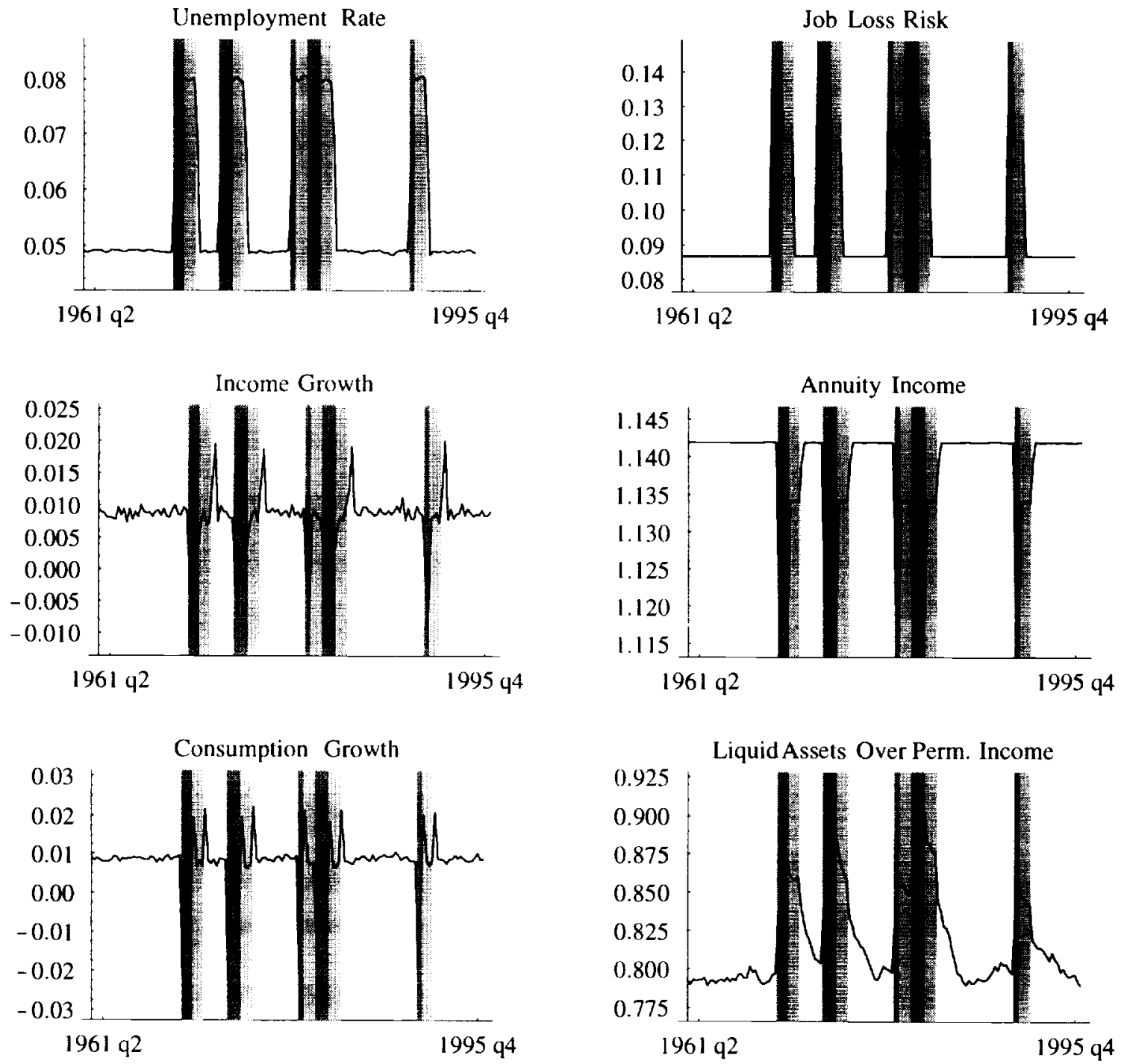

Figure 7: Simulated Economy with Actual Recession Pattern 

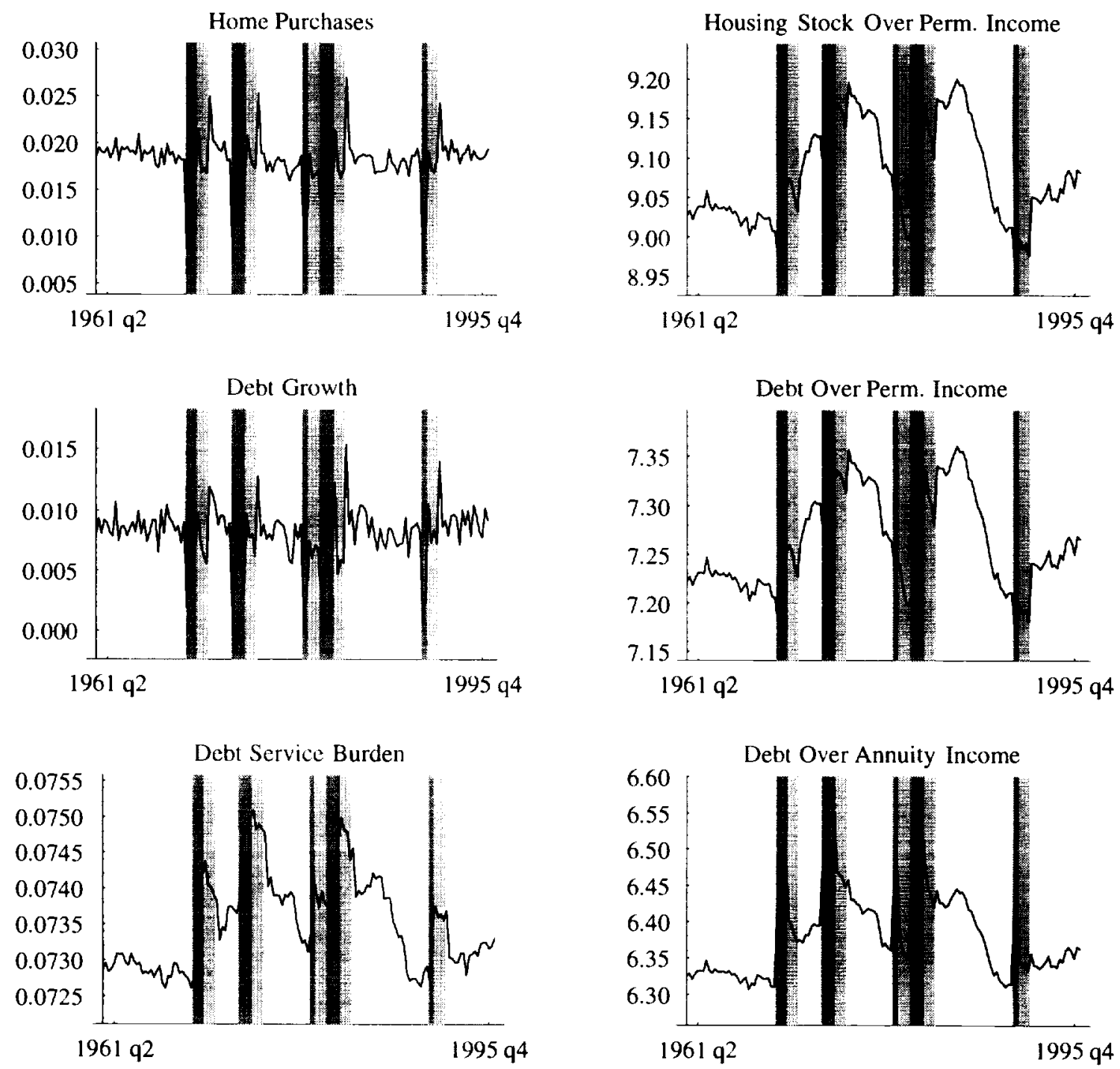

Figure 8: Housing, Debt, and Balance Sheets 


\subsection{Nondurables Consumption Growth}

We begin by examining the analogue to the Campbell-Mankiw equation estimated in the first part of the paper. The top panel of Table 7 reproduces the baseline sentiment-augmented Campbell-Mankiw equation from Table 1. The first row of the second panel of the table shows that when a standard Campbell-Mankiw equation is estimated on the simulated nondurables consumption data from our model, the forecastable component of income growth gets an insignificant and negative coefficient ${ }^{34}$

The second row shows that consumption growth is not significantly related to lagged unemployment expectations, again in accord with the CEQ PIH model and at variance iwth the empirical results. Finally, when both predictable income growth and lagged unemployment expectations are included, neither is significant at the 5 percent level. Thus, under baseline parameter values the model does not reproduce the empirical results we found when estimating the Campbell-Mankiw model in Table 1.

The next regressions examine the model's predictions for the explanatory power of lagged balance sheet measures. In accord with our cmpirical results, none of the balance sheet measures has any explantory power for nondurables consunption growth.

The next table exanines low nondurables consumption in our model responds to innovations to income and unemployment expectations; the corresponding US empirical results from Table 2 are again reproduced in the top panel. Recall that the CEQ PIH model would imply a coefficient of 1 on $\Delta \log A_{t}$ and zero on all other variables. while tle Campbell-Mankiw model with $\lambda=.5$ would imply coefficients of 0.5 on both $\Delta \log Y_{t}$ and $\Delta \log A_{t}$, but would still imply coefficients of zero on the UE variables. Row 3 of the second panel shows that under baseline parameter values our model implies a coefficient of about 0.49 on $\Delta \log Y_{t}$ and 0.59 on $\Delta \log A_{t}$. Both of these coefficients larger than the values estimated in the empirical data (row 0). However, the major difference between our model and either the CEQ PIH model or the Campbell-Mankiw model is our model's implication that both the lagged level and the change in UE should be highly statistically significant. ${ }^{35}$ This constitites at least a partial victory relative to the standard models which provide no role at all for unemployment expectations per se. However. it is fair to say that the model is at best a modest

\footnotetext{
${ }^{34}$ Under some alternative parametric assumptions the model does reproduce the Campbell-Mankiw finding. Given how long it takes to solve the model, we were unable to explore the parameter space sufficiently to determine what kinds of parametric combinations generate the Campbell-Mankiw result.

${ }^{35}$ Because the variables are defined ratle? differently, and scaled quite differently, it would not be appropriate to compare the coefficient estinates on lWE from the model to those from the data; hence we examine only statistical significance.
} 
Nondurable: Consumption Growth

Simulation Data

\begin{tabular}{|c|c|c|c|c|c|}
\hline Row/Measure & $E_{t-1} \Delta \log Y_{t}$ & $\mathrm{UE}_{t-1}$ & $\begin{array}{c}\text { Balance } \\
\text { Sheet }\end{array}$ & SSR & D-W \\
\hline \multicolumn{6}{|c|}{ Empirical Results (reproduced from Table 1) } \\
\hline 0 & $\begin{array}{r}0.269 \\
(1.64) \\
\end{array}$ & $\begin{array}{c}-0.906 \\
-(2.18)^{* *}\end{array}$ & & 0.50 & 1.98 \\
\hline \multicolumn{6}{|c|}{ Simulations Under Baseline Parameter Values } \\
\hline 1 & $\begin{array}{r}0.032 \\
(0.19) \\
\end{array}$ & & & 0.55 & 1.93 \\
\hline 2 & & $\begin{array}{c}0.404 \\
(1.45)\end{array}$ & & 0.55 & 1.81 \\
\hline 3 & $\begin{array}{r}0.244 \\
(1.31) \\
\end{array}$ & $\begin{array}{c}0.633 \\
(2.03)^{* *}\end{array}$ & & 0.47 & 1.97 \\
\hline $4 \Delta \log D_{t-1}$ & $\begin{array}{c}0.417 \\
(1.92)^{*}\end{array}$ & $\begin{array}{r}0.507 \\
(1.61)\end{array}$ & $\begin{array}{r}-0.394 \\
-(1.29)\end{array}$ & 0.42 & 1.98 \\
\hline $5 r D_{t-1} / Y_{t-1}$ & $\begin{array}{c}0.182 \\
(0.78)\end{array}$ & $\begin{array}{r}0.459 \\
(0.98)\end{array}$ & $\begin{array}{c}0.359 \\
(0.54)\end{array}$ & 0.49 & 1.97 \\
\hline $6 D_{t-1} / A_{t-1}$ & $\begin{array}{r}0.229 \\
(1.21)\end{array}$ & $\begin{array}{r}0.495 \\
(1.25) \\
\end{array}$ & $\begin{array}{r}0.007 \\
(0.57) \\
\end{array}$ & 0.47 & 1.97 \\
\hline \multicolumn{6}{|c|}{ Simulations After Financial Liberalization } \\
\hline 7 & $\begin{array}{r}-0.127 \\
-(0.62) \\
\end{array}$ & & & 0.73 & 1.96 \\
\hline 8 & & $\begin{array}{c}0.572 \\
(1.87)^{*}\end{array}$ & & 0.67 & 1.93 \\
\hline 9 & $\begin{array}{r}0.135 \\
(0.58) \\
\end{array}$ & $\begin{array}{c}0.698 \\
(1.90)^{*}\end{array}$ & & 0.62 & 2.00 \\
\hline
\end{tabular}

Table 7: The Campell-Mankiw Model Estimated on Simulated Data

success in explaining nondurables data, since it does not replicate the basic Campbell-Mankiw result.

Furthermore, even for the unemployment expecataions variable the match between theory and data is imperfect: the theory implies that the contemporaneous change in unemployment expectations should be vastly more important than the lagged level, but the empirical regressions found the opposite result. Carroll, Fuhrer, and Wilcox (1994) speculate that a model which incorporates both habit formation and labor income uncertainty might be able to explain the importance of lagged uncertainty for current consumption growth; a recent paper by Overland (1997) provides a formal underpinning for 
Nondurable Consumption Growth

Simulation Data

\begin{tabular}{|c|c|c|c|c|c|c|}
\hline Row & $\Delta \log Y_{t}$ & $\Delta \log A_{t}$ & $\mathrm{UE}_{t-1}$ & $\Delta \mathrm{UE}_{t}$ & $\bar{R}^{2}$ & D-W \\
\hline \multicolumn{7}{|c|}{ Empirical Results (reproduced from Table 2) } \\
\hline 0 & $\begin{array}{c}0.324 \\
(3.15)^{* * *}\end{array}$ & $\begin{array}{c}0.124 \\
(1.59)\end{array}$ & $\begin{array}{c}-1.003 \\
-(2.93)^{* * *}\end{array}$ & $\begin{array}{r}-0.907 \\
-(1.52)\end{array}$ & 0.34 & 1.92 \\
\hline \multicolumn{7}{|c|}{ Simulations Under Baseline Parameters } \\
\hline 1 & $\begin{array}{c}0.109 \\
(1.51)\end{array}$ & $\begin{array}{c}1.323 \\
(22.41)^{* * *}\end{array}$ & $\begin{array}{c}-3.398 \\
-(2.41)^{* *}\end{array}$ & & 0.86 & 2.44 \\
\hline 2 & $\begin{array}{c}0.078 \\
(1.85)^{*}\end{array}$ & & $\begin{array}{c}-4.470 \\
-(5.43)^{* * *}\end{array}$ & $\begin{array}{c}-5.561 \\
-(41.28)^{* * *}\end{array}$ & 0.95 & 1.86 \\
\hline 3 & $\begin{array}{r}-0.006 \\
-(0.21) \\
\end{array}$ & $\begin{array}{c}0 . \overline{486} \\
(12.08)^{* * *}\end{array}$ & $\begin{array}{c}-5.860 \\
-(10.07)^{* * *}\end{array}$ & $\begin{array}{c}-4.050 \\
-(25.94)^{* * *}\end{array}$ & 0.98 & 1.62 \\
\hline \multicolumn{7}{|c|}{ Simulations After Financial Liberalization } \\
\hline 4 & $\begin{array}{c}-0.032 \\
-(0.36)\end{array}$ & $\begin{array}{c}1.530 \\
(21.85)^{* * *}\end{array}$ & $\begin{array}{c}-4.394 \\
-(2.67)^{* * *}\end{array}$ & & 0.86 & 2.50 \\
\hline 5 & $\begin{array}{r}-0.054 \\
-(1.05) \\
\end{array}$ & & $\begin{array}{c}-5.434 \\
-(5.56)^{* * *}\end{array}$ & $\begin{array}{c}-63.926 \\
-(39.55)^{* * *}\end{array}$ & 0.95 & 1.76 \\
\hline 6 & $\begin{array}{c}-0.186 \\
-(5.36)^{* * *}\end{array}$ & $\begin{array}{c}0.596 \\
(13.75)^{* * *}\end{array}$ & $\begin{array}{c}-7.510 \\
-(11.59)^{* * *}\end{array}$ & $\begin{array}{l}-46.023 \\
-(27.59)^{* * *}\end{array}$ & 0.98 & 1.57 \\
\hline
\end{tabular}

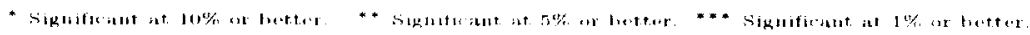

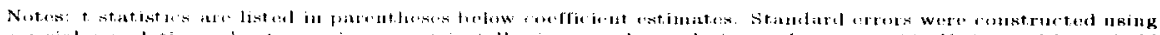

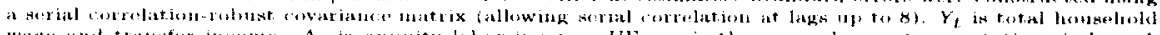

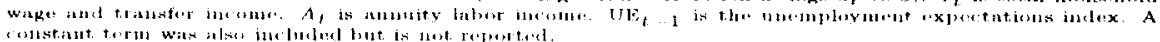

Table 8: Effect of Innovations on Nondurables Consumption 
this idea. Alternatively, it may take consumers time to formulate new spending plans upon receipt of new information; this could be formalized in a model in which consumers draw up budgets only periodically, and do not change their spending patterus until they find the time to draw up a new budget.

\subsection{The Cyclical Dynamics of Durables Spending}

Table 9 presents the results when we estimate equations for our simulated home sales data similar to those estimated earlier for both NIPA durable goods and total US home sales; again the corresponding empirical result is reproduced in the first row of the table. ${ }^{36}$

In our simulated data the ammity income ratio is insignificant but both the lagged level of unemployment expectations and the change in unemployment expectations are highly significant. Here the level and the change in the level of the unemployment expectations index are roughly equally statistically significant.

Turning to the balance sheet variables, lagged debt growth receives a positive and significant coefficient; recall that it was the only balance sheet variable that was robustly significant in the NIPA data. Although simultaneity seemed the nost plausible interpretation for the empirical results there was no obvious way to prove that simultaneity was the correct interpretation. Here the answer is clear: simultaneity is the culprit. Debt growth is acting as a statistic for all of those characteristics of the aggregate enviromment which are inportant in deternining the pace of home sales but are not captured by the other observed aggregate variables. For example, during the course of recessions home sales and debt growth both plummet initially, but recover substantially over the succeeding few quarters (even while the economy remains in recession). The partial recovery in sales reflects a combination of the buildup of consumer's' buffer-stocks of precautionary savings and the continuing depreciation of their homes (moving some of then across even a lowered (S,s) trigger). These changing circumstances are not captured by our observed aggregate variables, but they are at least partly captured by lagged debt growth. Hence lagged debt growth's statistical significance is entirely attributable to the fact that it is an endogenous variable responding to unobserved but important real determinants of home

\footnotetext{
${ }^{36}$ Here we take the "corresponding" result from the table on durable goods spending rather than the table on home sales. Although we calibrate our model to match certain features of the housing market, it is clear that under alternative parameter values the model could equally be interpreted as a model of purchases of automobiles or other durable goods. Given the similarity of the empirical results for lome sales and durable good sales documented in Tables 3 and 5 , it is of little consequence whether we compare our model's predictions to the pattern of durable goods sales or home sales.
} 
Home Sales

Simulated Data

\begin{tabular}{|c|c|c|c|c|c|c|c|}
\hline Row/Measure & $A_{t-1} / A_{t}$ & $\mathrm{UE}_{t-1}$ & $\Delta \mathrm{UE}_{t}$ & $Y_{t} / A_{t}$ & $\begin{array}{c}\text { Balance } \\
\text { Sheet } \\
\text { Measure }\end{array}$ & $\bar{R}^{2}$ & $\mathrm{D}-\mathrm{W}$ \\
\hline \multicolumn{8}{|c|}{ Empirical Baseline (reproduced from Table 5) } \\
\hline 0 & $\begin{array}{c}-0.542 \\
-(3.48)^{* * *}\end{array}$ & $\begin{array}{c}-7.471 \\
-(4.21)^{* * *}\end{array}$ & $\begin{array}{r}-1.541 \\
-(0.70) \\
\end{array}$ & $\begin{array}{c}1.172 \\
(2.99)^{* * *} \\
\end{array}$ & & 0.51 & 0.33 \\
\hline \multicolumn{8}{|c|}{ Simulations Under Baseline Parameters } \\
\hline 1 & $\begin{array}{c}0.037 \\
(0.85) \\
\end{array}$ & $\begin{array}{c}-5.260 \\
-(8.07)^{* * *} \\
\end{array}$ & $\begin{array}{c}-19.407 \\
-(10.55)^{* * *}\end{array}$ & $\begin{array}{c}-0.106 \\
-(2.57)^{* * *}\end{array}$ & & 0.76 & 1.80 \\
\hline $2 \Delta \log D_{t-1}$ & $\begin{array}{r}0.048 \\
(1.14) \\
\end{array}$ & $\begin{array}{c}-4.047 \\
-(5.50)^{* * *} \\
\end{array}$ & $\begin{array}{c}-20.452 \\
-(11.31)^{* * *}\end{array}$ & $\begin{array}{c}-0.081 \\
-(1.98)^{* *}\end{array}$ & $\begin{array}{c}0.179 \\
(3.20)^{* * *}\end{array}$ & $0 . \overline{77}$ & 2.16 \\
\hline $3 r D_{t-1} / Y_{t-1}$ & $\begin{array}{r}0.043 \\
(0.98) \\
\end{array}$ & $\begin{array}{c}5.780 \\
-(7.63)^{* * *}\end{array}$ & $\begin{array}{c}-19.641 \\
-(10.66)^{* * *}\end{array}$ & $\begin{array}{c}-0.100 \\
-(2.41)^{* *}\end{array}$ & $\begin{array}{c}0.154 \\
(1.33) \\
\end{array}$ & 0.76 & 1.79 \\
\hline $4 D_{t-1} / A_{t-1}$ & $\begin{array}{r}0.026 \\
(0.57) \\
\end{array}$ & $\begin{array}{c}-4.875 \\
-(5.49)^{* * *} \\
\end{array}$ & $\begin{array}{c}-19.227 \\
-(10.31)^{* * *} \\
\end{array}$ & $\begin{array}{c}-0.096 \\
-(2.16)^{* *}\end{array}$ & $\begin{array}{r}-0.002 \\
-(0.64)\end{array}$ & 0.76 & 1.79 \\
\hline \multicolumn{8}{|c|}{ Simulations After Financial Liberalization } \\
\hline 5 & $\begin{array}{c}-0.189 \\
-(2.71)^{* * *}\end{array}$ & $\begin{array}{c}-7.020 \\
-(6.67)^{* * *} \\
\end{array}$ & $\begin{array}{l}-21.149 \\
-(6.74)^{* * *}\end{array}$ & $\begin{array}{c}-0.296 \\
-(4.56)^{* * *}\end{array}$ & & 0.80 & 1.93 \\
\hline
\end{tabular}

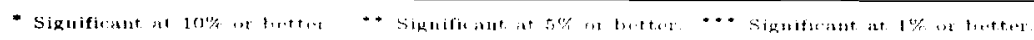

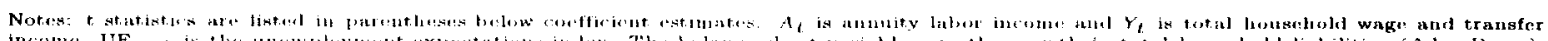

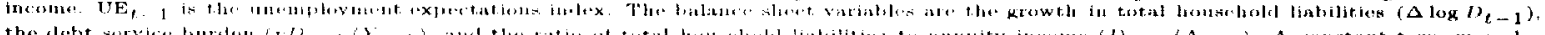

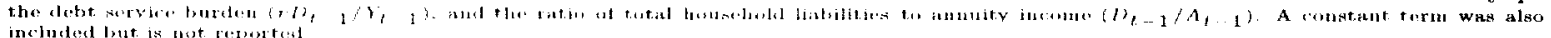

Table 9: Home Sales in the Simulated Economy

sales.

The remainder of Table 9 shows that the other two lagged balance sheet variables are not systematically related to horne sales (as they were not in the empirical data). The reason can be seen in Figure 8: the debt to income ratio and the debt service burden tend to be high during recessions because income is temporarily low, but also tend to be high in recoveries and early expansions, because upon recovery the pent-up demand built up during the recession is satisfied by a large number of home purchases and a consequent runup in aggregate debt. Hence both variables tend to be higher than average both during periods of particularly low sales (recessions) and particularly high sales (early recoveries and expansions).

The fundamental question these regressions are designed to address is whether our model performs better than the standard models in explaining our empirical findings in Tables 3,4 and 5 . On the whole, the answer is yes. Our model inplies a very important role for unemployment expectations 
beyond any correlation they may have with current or expected future levels of income. And it provides an interpretation for the finding that lagged debt growth is consistently positively related to current home sales and that other balance sheet measures are not consistently related to home sales. However, as in the nondurables regressions, the model implies a much stronger reaction to innovations in uncertainty than we observe empirically. We speculated above that habit formation might explain the sluggishness of nondurables consumption witl respect to unemployment expectations innovations; for durable goods, however, time-to-build or decision lag considerations seem more plausible. This is especially so for housing decisions: a consumer who has gone to the trouble of house-hunting, lining up financing, negotiating and bidding on a house is unlikely to back out at the last moment because of a sudden change in unemployment expectations. Similar but less forceful arguments apply for automobile purchiases.

\subsection{The Cyclical Dynamics of Debt Growth}

In the model, the prinary determinant of debt growth is home sales. Indeed, since all debt is used for home purchases, and since the value of all homes purchased is in exactly the same proportion to the permanent labor incone of the buyer. one night think that the model implies that data on home sales should explain 100 percent of the variation on debt growth. A glance at figure 6 will confirm that the patterns of lieme sales and debt growth over the cycle are indeed quite similar. However, the model does provide several channels through which other variables influence aggregate debt growth. First, a small number of consumers who have experienced a particularly nasty series of shocks find themselves forced to sell their homes and rent temporarily in order to get access to the emergency reseve of precautionary resources represented by their home equity. Second, among the consumers who are currently renting, fewer will be willing to buy new homes when unemployment expectations are pessimistic. The number of consumers who are forced to sell and rent will obviously be on average related to the level and change of unemployment expectations. Finally, note that the fact that the $(\mathrm{S}, \mathrm{s})$ trigger jumps around means that even though every purchase represents exactly the same amount of debt acquisition (relative to the permanent income of the buyer), every sale does not reflect the same amount of debt retired. Hence we should expect variables that affect the location $(\mathrm{S}, \mathrm{s})$ trigger to have an effect on debt growtll. 
Growth in Total Household Liabilities

Simulated Data

\begin{tabular}{|c|c|c|c|c|c|c|c|}
\hline Row/Measure & $H_{t}$ & $\mathrm{UE}_{t-1}$ & $\Delta U E_{t}$ & $\Delta \log A_{t}$ & $\begin{array}{c}\text { Balance } \\
\text { Sheet } \\
\text { Measure } \\
\end{array}$ & $\bar{R}^{2}$ & $\mathrm{D}-\mathrm{W}$ \\
\hline \multicolumn{8}{|c|}{ Empirical Baseline (reproduced from table 6) } \\
\hline 0 & $\begin{array}{c}0.130 \\
(5.90)^{* * *}\end{array}$ & $\begin{array}{c}-2.867 \\
-(6.41)^{* * *}\end{array}$ & $\begin{array}{c}-1.6 \overline{62} \\
-(2.42)^{* *}\end{array}$ & $\begin{array}{r}0.059 \\
(0.79) \\
\end{array}$ & & & 2.12 \\
\hline \multicolumn{8}{|c|}{ Simulations Under Baseline Parameters } \\
\hline 1 & $\begin{array}{c}0.826 \\
(20.95)^{* * *}\end{array}$ & & & & & 0.76 & 2.07 \\
\hline 2 & $\begin{array}{c}0.812 \\
(20.88)^{* * *}\end{array}$ & $\begin{array}{c}-1.419 \\
-(2.81)^{* * *}\end{array}$ & & & & 0.77 & 2.22 \\
\hline 3 & $\begin{array}{c}0.805 \\
(10.36)^{* * *}\end{array}$ & $\begin{array}{c}-1.465 \\
-(2.24)^{* *}\end{array}$ & $\begin{array}{r}-0.203 \\
-(0.11) \\
\end{array}$ & & & 0.77 & 2.22 \\
\hline 4 & $\begin{array}{c}0.791 \\
(13.54)^{* * *} \\
\end{array}$ & $\begin{array}{c}-1.564 \\
-(2.67)^{* * *} \\
\end{array}$ & & $\begin{array}{r}0.017 \\
(0.49) \\
\end{array}$ & & 0.77 & 2.23 \\
\hline 5 & $\begin{array}{c}0.806 \\
(10.34)^{* * *}\end{array}$ & $\begin{array}{l}1.477 \\
-(2.25)^{* *} \\
\end{array}$ & $\begin{array}{r}0.726 \\
(0.30) \\
\end{array}$ & $\begin{array}{r}0.026 \\
(0.56) \\
\end{array}$ & & 0.77 & 2.24 \\
\hline $6 \Delta \log D_{t-1}$ & $\begin{array}{c}0.826 \\
(21.43)^{* * *} \\
\end{array}$ & $\begin{array}{l}-2.324 \\
(3.79)^{* * *}\end{array}$ & & & $\begin{array}{c}-0.126 \\
-(2.51)^{* * *}\end{array}$ & 0.78 & 1.94 \\
\hline $7 r D_{t-1} / Y_{t-1}$ & $\begin{array}{c}0.825 \\
(21.25)^{* * *} \\
\end{array}$ & $\begin{array}{r}-0.673 \\
-(1.11) \\
\end{array}$ & & & $\begin{array}{c}-0.223 \\
-(2.17)^{* *} \\
\end{array}$ & 0.78 & 2.20 \\
\hline $8 D_{t-1} / A_{t-1}$ & $\begin{array}{c}0.811 \\
(20.88)^{* * *}\end{array}$ & $\begin{array}{r}-0.916 \\
-(1.41) \\
\end{array}$ & & & $\begin{array}{r}-0.003 \\
-(1.23) \\
\end{array}$ & 0.77 & 2.21 \\
\hline
\end{tabular}

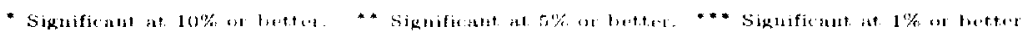

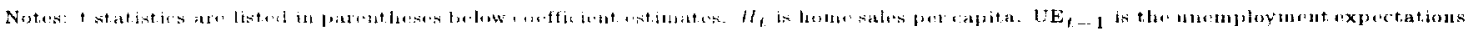

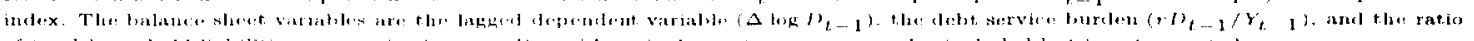

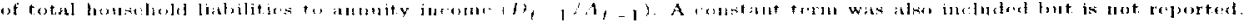

Table 10: Debt Growth and its Correlates

Table 10 presents the results when we estimate regressions for debt growth like those estimated in Table 6 above. As expected (and as in the ompirical data), debt growth is very closely related to home sales; when the pace of home sales is the only regressor, the $\bar{R}^{2}$ is 0.76 . However, the next regression shows that the lagged level of the unemployment expectations index does provide additional explanatory power for debt growth (again corresponding to the empirical result). When we add the growth rate of annuity income to this baseline regression, the innovation to annuity income is not statistically significant, in contrast with the empirical regressions. In contrast to the results for durable and nondurable goods, the change in unemployment expectations is not statistically significant. Finally, we consider the lagged balance sheet measures, all of which are negatively correlated with current debt growth. These results contrast with the empirical regressions, in which the lagged dependent variable 
received a strongly positive coefficient and the other balance sheet measures were insignificant.

In sum, the model captures (almost by assumption) the strong empirical correlation between home sales and debt growth, but, in contrast with a CEQ PIH model or a standard (S,s) model it also provides an interpretation for the emprical finding that unemployment expectations are significantly related to debt growth. It does not. however, imply the observed empirical positive autocorrelation in debt growth after unemployment expectations have been controlled for.

\subsection{Summary}

The analysis of this section has attempted to determine whether our model does a better job than standard models of explaining the empirical regularities relating nondurable consumption growth, durables purchases, and balance sheet variables. The model is successful in that it implies an important role for unemployment expectations in addition to the expected level of future income. However, it also suggests that there is a paradox about the role of unemployment expectations: while the model implies that consumption growth, durables purchases, and debt acquisition should be strongly affected by changes in memployment expectations, our empirical work found that the lagged level of expectations was always much more statistically important than the change in expectations.

\section{Was the 1990 Recession "Special"?}

To this point in the paper we have not directly addressed the question of whether the 1990 recession was "special" in any sense, although we motivated the paper by noting that common analyses of the 1990 recession attributed the unusual consumption weakness to 'household debt overhang.' In this section we examine first the theory and then the evidence.

\subsection{Theory}

\subsubsection{The Dynamic Response to Deregulation}

As briefly noted earlier, prior to the 1990 recession there was a rapid and considerable runup in the ratio of houselold debt to income (see Figure 1). The most plausible explanation is that this was the consequence of the wide-ranging deregulation of financial markets that took place in the late 1970 s and early 1980s.

Capturing the full complexity of financial deregulation is obviously beyond the scope of the model 

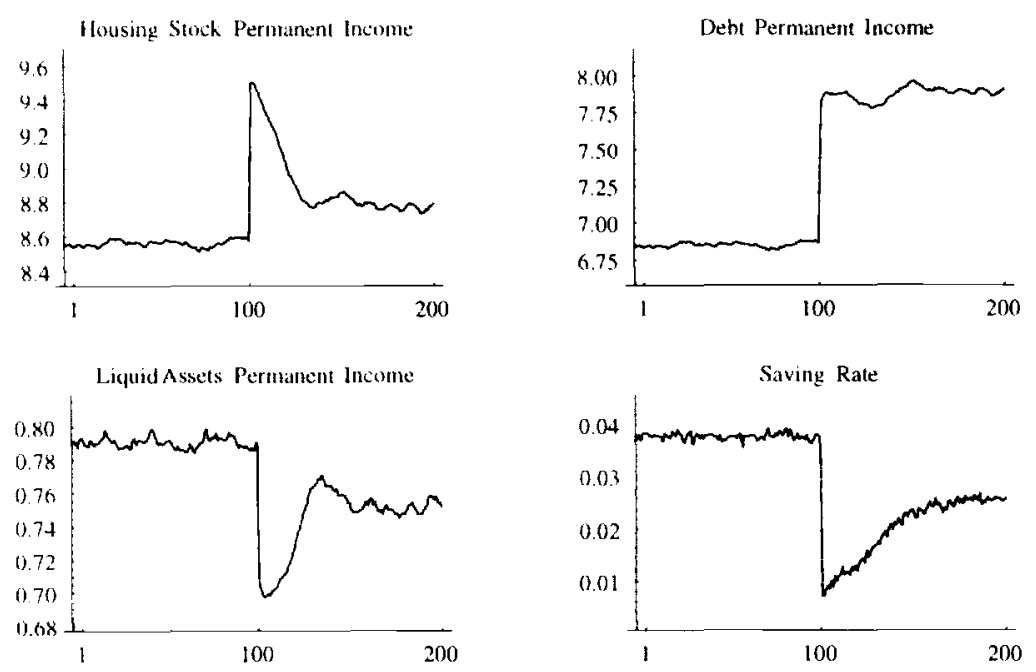

Figure 9: Dynamic: Path Of Economy After Financial Liberalization

introduced above. However. both before and after deregulation, home mortgage borrowing was by far the largest component of total houselold debt. To the extent that the main effect of deregulation was to make mortgage borrowing easier by reducing required down payments, our model can be used to get a sense of the likely effects of deregulation. The particular experiment we consider is a one-off reduction in the downpayment requirement from our $20 \%$ baseline assumption to $10 \%$. Of course the progress of credit liberalization was in reality much more gradual, but this experiment should at least give a sense of the likely results of a more gradual deregulation.

In the short term, the effects of deregulation are very similar to those of moving from a recession to an expansion: the bottom of the (S.s) band jumps upward instantly. Figure 9 depicts the results of reducing the dowluayment requirement for an economy which had previously been in stochastic steady-state equilibrium. The inmediate effect of deregulation is to spur an avalanche of home sales, which is accompanied by a massive cuntup in debt and consequently a large increase in the aggregate debt to income ratio. Eventually the level of housing per capita falls most of the way (although not all the way) back to its original steady-state level, but the ratio of debt to income plateaus at a substantially higher level. The level of liquid assets immediately drops sharply, as most of the consumers who had been saving up for a down paynent now find that, in combination with the equity from their previous honc, their current stock of liquid assets is enough to cover the new lower down payment requirement. The level of liquid assets graclually rebounds a bit as new homeowners struggle 
to build up their buffer-stocks of liquicl assets to the target level, but the new steady-state level of liquid assets is well below its pre-deregulation equilibrium. This reflects the fact that a substantial part of the average stock of liquid assets represented saving for down payments rather than precautionary saving. The consequences of deregulation for the aggregate saving rate are particularly interesting: in the three or four years after deregulation it drops from about $2-3 / 4$ percent to under one percent, but eventually recovers a bit to settle down at slightly less than two percent. The U shape in the saving rate reflects the fact that for quite a while after deregulation luost of the housing stock still consists of homes bought in the pre-deregulation period when the down payment requirement was higher. These homeowners on average lieed to do very little downpayment saving, because the comparatively large equity in their previous home is by itself almost enough for the down payment on the new home. Eventually, however. the ontire lousing stock is composed of homes bought after liberalization and consumers have to boost their saving somewhat in order to accumulate downpayments again.

\subsubsection{Cyclical Properties of the Deregulated Economy}

From the standpoint of cyclical analysis, perhaps the llost interesting question to ask about the deregulated economy is whether the highel prevailing debt burdens make aggregate consumption more volatile and in particular nore responsive to unemploynent expectations. We address this question by repeating the simulation and regression analysis of section 5 for a deregulated economy that is otherwise identical to our baseline economy.

The bottom panels of Tables 7 and 8 present the results for the nondurables regressions in the deregulated economy. Results are on the whole not much different: both forecastable income growth and lagged mnemployment expectations remain statistically insignificant, as do the balance sheet variables (not reported). Nondurables consumption does react a bit more strongly to a change in unemployment expectations, but the change is modest.

The botton panel of Table 9, however, shows that home sales are more sensitive to unemployment expectations in the high-debt econony: the coefficient on the lagged level of unemployment expectations changes from about -5 to about -7 and the coefficient on the change in unemployment expectations increases from about -19 to about $-21 .{ }^{37}$ Meanwhile, the annuity income ratio (which

\footnotetext{
${ }^{37}$ This increase in the siguifiance of $\mathrm{UE}$ is the smallest increase we found under any combination of parameter values we checked. In the original draft of the paper, the coeficient on $\mathrm{UE}_{t-1}$ almost doubled.
} 
Ratio of Durables Consumption to Annuity Labor Income

$1963: 2-1994: 3$

\begin{tabular}{|c|c|c|c|c|c|c|}
\hline Row & $\mathrm{UE}_{t}$ & $\mathrm{UE}_{t}^{\text {Ta*t*5. }}$ & $\Delta \mathrm{UE}_{t}$ & $\Delta \mathrm{UE}_{t}^{\text {Pout 85 }}$ & $\bar{R}^{2}$ & $\mathrm{D}-\mathrm{W}$ \\
\hline 1 & -2.320 & & 0.723 & & 0.43 & 0.54 \\
& $-(6.19)^{* * *}$ & & $(1.06)$ & & & \\
\hline 2 & -2.032 & -2.144 & 0.385 & & 0.46 & 0.55 \\
& $-(6.39)^{* * *}$ & $-(2.60)^{* * *}$ & $(0.66)$ & & & \\
\hline 3 & -2.341 & & 0.486 & 1.322 & 0.43 & 0.54 \\
& $-(6.28)^{* * *}$ & & $(0.71)$ & $(0.85)$ & & \\
\hline 4 & -2.051 & -2.076 & 0.283 & 0.626 & 0.46 & 0.56 \\
& $-(6.43)^{* * *}$ & $-(2.34)^{* *}$ & $(0.42)$ & $(0.38)$ & & \\
\hline
\end{tabular}

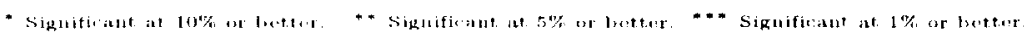

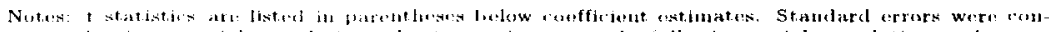

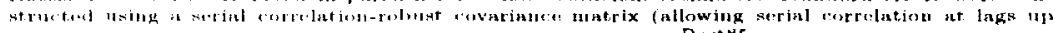

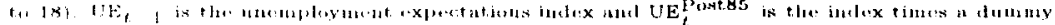

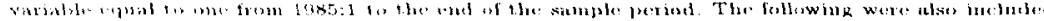

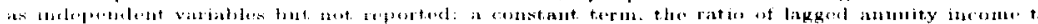

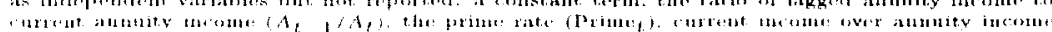

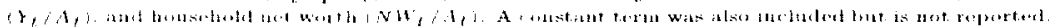

Table 11: Interaction Term in Durables Regressions

was insignificant in the baseline economy) becomess statistically significant.

There are several reasons why home sales are more sensitive to uncertainty in the liberalized economy. The most important is probably simply that buying a house is a considerably riskier financial venture, for two reasons. First, and most important. there is a great deal less home equity available as an emergency reserve against major clisasters (a long unemployment spell or a substantial reduction in the level of permanent income). Second is a mechanism emphasized by Fratantoni (1996): because mortgage payments cannot be altered once the mortgage is taken out, all adjustment of consumption to any income shocks must be borne entirely by nondurables consumption. The larger mortgage payment associated with a lower down payment thus implies that at any given amount of liquid wealth, any given anount of uncertainty will have a greater impact on nondurables consumption.

One way to think about these results is to consider the large down payment requirement as a form of "forced saving" which, essentially as a side-effect, also serves a precautionary role. When the amount of forced saving declines, consumers must partially replace the effective precautionary buffer that the forced saving provided by reacting more with their "discretionary" precautionary behavior.

These results supply a potential theretical underpinning for the idea that the runup in consumer debt in the late 1980 s was at least partly responsible for the severity of the decline in consumer spending, particularly on durable goods. in the recession and subsequent slow recovery in the early 
1990s. However, the rise in debt-to-income ratios is not, in this interpretation, the driving force in the story; rather, both the increase in debt and an increased sensitivity of durables spending to unemployment expectations are encrgent properties of the new stochastic equilibrium with deregulated credit markets.

It is worth emphasizing here how surprising this theoretical result is. The usual economic intuition is that relaxation of liquidity constraints should allow consumers to smooth consumption more. Here, a relaxation in liquidity constraints has exactly the opposite effect.

\subsection{Empirical Evidence}

We turn, finally, to the question of whether there is any empirical evidence for the proposition that in the wake of financial deregulation durables spending has become more sensitive to unemployment expectations. We first perform the simplest possible test by exanining whether the coefficient on the unemployment expectations variables has been significantly higher in the post-deregulation period than in the pre-deregulation period. The principal difficulty in performing this test is in deciding when to date the dercgulation from. The initial stages of deregulation took place in the late 1970s during the Carter administration, and the policy reforms were largely complete by 1983 . However, arguably the most important development (at least from the standpoint of its effect on the availability of mortgage credit) in the liberalized market was the rapid growth of the secondary market for mortgage debt fostered by the Federal National Mortgage Association and similar government sponsored enterprises. The associated rapid growth in mortgage debt appears to have begun around 1985 . We therefore date the post-liberalization period as begiming in 1985 (although our empirical results are not sensitive to the exact (lates we (looses).

Results are presented in Table 11. The interaction term on the level of unemployment expectations is highly statistically significant, and implies that the coefficient on unemployment expectations was roughly twice as large in the post-liberalization period as in the earlier period ${ }^{38}$ However, the coeffcient on the interaction term is insignificant for the variable measuring the change in unemployment expectations. once again refecting our general empirical finding that the change in unemployment expectations is not nearly as reliably important as the level in influencing consumption choices.

\footnotetext{
${ }^{38}$ We found similar results when we allowed all regression coefficients (not just the coefficients on the UE terms) to differ pre- and post-1985.
} 


\section{Conclusions}

The broad goal of this paper lias been to document and then explain the relationships between household balance sheets and consumer purchase decisions. In our empirical work we found that unemployment expectations appear to have an influence on spending decisions beyond any information those expectations contain about future levels of income. We therefore develop a theoretical model of debt-financed durables purchises which has a serious role for labor income uncertainty. This model implies that the location of the lower $(S, s)$ trigger depends on the degree of labor income uncertainty; when uncertainty increases consumers postpone durables purchases until their balance sheet condition improves. Wo find that this modol clocs a much better job than the standard certainty equivalent or fixed-band $(S, s)$ models at explaining the cyclical dynamics of spending and balance sheets. However, the model does highlight a paradox: it is the lagged level of unemployment expectations, rather than the change in expectations (which the model emphasizes), that appears to be related to spending decisions.

This paper suggests a variety of important directions for future work. First, the calibration of the model was necessarily ad hoc. There appears to be surprisingly little data available about such important questions as how the risk of job loss changes over the business cycle, or how the job-finding hazard changes for those: who are unemployed. Given the apparent empirical and theoretical importance of labor income uncertainty, this is an area where very useful work could be done. Second, the analysis of this paper treated memployment expectations and the aggregate economic state as exogenous. Although in the wake of the "rational expectations revolution" in macroeconomics it sounds staggering to say it, to our knowledge there has been virtually no recent research on how consumers' observable expectations are determined, either for the unemployment expectations variable we consider or for any of the other aggregate measures of consumer expectations. There are presumably many tests that could be performed to determine, for example, the rationality of those expectations. Fourth, the extreme short-term response of durables spending to uncertainty clearly raises the possibility of multiple equilibria in a general equilibrium version of this model. Although solving the full model in a general equilibrium setting is clearly well beyond current computational capacities, it is possible that simplified models which build in an extreme sensitivity of clurables spending to uncertainty might be solvable. Finally, the model has many implications that are testable with microeconomic data. For 
example, a straightforward test would be to estimate a probit model of home purchase decisions and to test whether the purchase decision is affected by either local or aggregate unemployment expectations. 


\section{References}

AdDA, J., AND R. COOPER (1997): "Balladurette and Juppette: A Discrete Analysis of Scrapping Subsidies," Manuscript, Departmcnt of Economics, Boston University.

Bar-Ilan, A., AND A. S. Blinder (1992): "Consumer Durables: Evidence on the Optimality of Usually Doing Nothing." Journal of Money. Credit, and Banking, 24(2), 258-272.

Bernanke, B., G. Flerrri, anI) P. Simon (1997): "Is 'There a Flight to Quality in Consumer Lending?." Manuscript, Princeton University.

Bernanke, B.. M. Gertler, and S. Gll.hnzist (1996): "The Financial Accellerator and the Flight to Quality," Review of Economics and Statistics, 78, 1-15.

BernankE, B. S. (1983): "Irreversibility, Uncertainty, and Cyclical Investment," Quarterly Journal of Economics, 98(1), 85-106.

(1984): "Permanent Income, Licquidity, and Expenditure on Automobiles: Evidence From Panel Data," Quarterly Journal of Economics, 99(3), 587-614.

(1985): "Adjustment Costs. Durables, and Aggregate Consumption," Journal of Monetary Economics, $15(1), 41 \cdots 68$.

Bertola, G., and R. J. Cabalıtero (1990): "Kinked Adjustment Costs and Aggregate Dynamics," in NBER Macrocconomics Annual. ed. by O. J. Blanchard. and S. Fischer, pp. 237-288. MIT Press, Cambridge, MA.

(1994): "Irreversibility and Aggregate Investment," Review of Economic Studies, 61(2), $223-246$.

Blanchard. O. J. (1993): "What Caused the Last Recession? Consumption and the Recession of 1990-1991." American Economic Review, 83(2), 270-274.

Caballero, R. J. (1993): "Durable Goods: An Explanation for Their Slow Adjustment," Journal of Political Economy, 101(2), 351-384. 
Caballero, R. .J. Ani) E. M. R. A. En(iEl (1994); "Explaining Investment Dynamics in U.S. Manufacturing: A Generalized (S.s) Approach," NBER Working Paper No. 4887.

Campbell. J. Y. (1987): "Does Saving Anticipate Declining Labor Income? An Alternative Test of the Permanent Income Hypothesis,." Econometrica, 55, 1249-73.

Campbell. J. Y. and A. S. Deaton (1989): "Why Is Consumption So Smooth?," Review of Economic: Studies, 56.35774

Campbell, J. Y., anid N. G. Mankiw (1989): "Consumption, Income, and Interest Rates: Reinterpreting the Time-Series Evidence," in NBER Macroeconomics Annual, 1989, ed. by O. J. Blanchard, and S. Fischer, pp. 185 216. MIT Press, Cambridge, MA.

Caplin, A., and J. Leahy (1997): "Durable Goods Cycles," Manuscript, Boston University.

Carrington. W. J. (1993): "Wage Losses for Displaced Workers," Journal of Human Resources, XXVIII(3), $435-62$.

Carroll. C. D. (1992): "The Buffer-Stock theory of Saving: Some Macroeconomic Evidence," Brookings Paperss on Economic Activity. 1992(2), 61156.

(1997): "Buffer-Stock Saving and the Lifo Cycle/Permanent Income Hypothesis," Quarterly Journal of Economies. CXII(1), 156.

Carroll, C. D., and W. E. Dunn (1997): "Data Sources and Solution Methods for Empirical and Theoretical Results in 'Unemployment Expectations, Jumping (S,s) Triggers, and Household Balance Sheets:." http://wuru: econ.jhu.edu/ccarroll.

Carroll, C. D.. J. C. Flhrer, and D. W. Wilcox (1994): "Does Consumer Sentiment Forecast Household Spending? If So, Why?," American Eronomic: Review, 84(5), 1397 1408.

Carroll, C. D., and M. S. Kimball (1996): "On the Concavity of the Consumption Function," Econometrica, 64(4), 981992.

Carroll, C. D., and A. A. Samwick (1997): "The Nature of Precautionary Wealth," Forthcoming, Journal of Monetary Economics, 40(1). 
Deaton, A. S. (1991): "Saving and Liquidity Constraints," Econometrica, 59, 1221-1248.

Dixit, A. K. AND R. S. Pindyck (1994): Investment Under Uncertainty. Princeton University Press, Princeton, N.J.

EberLy, J. C. (1997): "Flexible (S.s) Bands, Uncertainty, and Aggregate Consumer Durables Purchases," Working Paper. University of Pennsylvania.

Fannie Mat Folinidation (1997): "Opening the Door to a Home of Your Own," Washington, D.C.

Fratantoni, M. C. (1996): "Housing Wealth, Precautionary Saving and the Equity Premium," Manuscript, The Johns Hopkins University.

Garner, C. A. (1996): "Can Measures of the Consumer Debt Burden Reliably Predict an Economic Slowdown?." Federal Reserve Bank of Kansas City, 81(4), 63-76.

Greenspan, A. (1992): "Statement to the U.S. House Committee on Ways and Means, December 18, 1991." Federal Reserve Bulletin, $78(2), 122124$.

Greenspan. A.. and D. Cohen (1997): "Motor Vehicle Stocks, Scrappage, and Sales," Manuscript, Board of Governors of the Federal Reserve System.

Grossman, S. J., and G. S. Laroque (1990): "Asset Pricing and Optimal Portfolio Choice in the Presence of Illiquid Durable Consumption Goods." Econometrica, 58(1), 25-51.

HaLl, R. E. (1978): "Stochastic: Inplications of the Life-Cycle/Permanent Income Hypothesis: Theory and Evidence," Journal of Political Economy, 96, 97187.

(1993): "Macro 'Theory and the Recession of 1990-1991," American Economic Review, 83(2), $275-279$

Kimball, M. S. (1990): "Precautionary Saving and the Marginal Propensity to Consume," NBER Working Paper Number 3403.

Ludvigson. S. (1996): "Consumption aud Credit: A Model of Time-Varying Liquidity Constraints," Ph.D. thesis, Princeton University. 
Mankiw, N. G. (1982): "Hall's Consunuption Hypothesis and Durable Goods," Journal of Monetary Economics, 10(3), 417425 .

McCARThy, J. (1997): "Does the Household Balance Sheet Affect Expenditures Response to Monetary Policy?." Manuscript, Federal Reserve Bank of New York.

Mishkin, F. S. (1976): "Illiquidity, Consumer Durable Expenditure, and Monetary Policy," American Economic Reviem, 66(4), 642-654.

(1977): "What Depressed the Consumer? The Household Balance Sheet and the 1973-75 Recession." Brookings Papers on Economic Activity, 1977:1, pp. 123-164.

— (1978): "Consumer Sentinent and Spending on Durable Goods," Brookings Papers on Economic Activity, 1978:1, pp. 217231.

Overland, J. (1997): "Optimal Saving with Stochastic Income and Habit Formation," Manuscript, Brown University.

Sichel, D. S. (1993): "Business Cycle Asymmetries: A Deeper Look," Economic Inquiry, pp. 224236.

(1994): "Inventories and the "Three Stages of the Business Cycle," Journal of Business and Economic Statistics, 12, 269-277.

WILCox. D. W. (1992): "The Construction of U.S. Consumption Data: Some Facts and Their Implications for Empirical Work." American Economic Review, 82(4). 922-941. 